\title{
Origin and provenance of igneous clasts from late Palaeozoic conglomerate formations (Del Ratón and El Planchón) in the Andean Precordillera of San Juan, Argentina
}

\author{
G. Gallastegui ${ }^{1 *}$, L. González-Menéndez² , A. Rubio-Ordóñez ${ }^{3}$ A. Cuesta ${ }^{3}$, A. Gerdes ${ }^{4}$ \\ ${ }^{1}$ Instituto Geológico y Minero de España (IGME). C/ Matemático Pedrayes 25, 33005 Oviedo, Spain. \\ ${ }^{2}$ Instituto Geológico y Minero de España (IGME). C/ Real 1, 24006 León, Spain. \\ ${ }^{3}$ Departamento de Geología, Universidad de Oviedo. C/ Jesús Arias de Velasco, s/n, 33005 Oviedo, Spain. \\ ${ }^{4}$ Institut für Geowissenschaften Mineralogie, Abt. Geochemie \& Petrologie, Altenhöferallee 1, D-60438 Frankfurt \\ am Main, Germany.
}

e-mail addresses: g.gallastegui@igme.es (G.G., *correspondingauthor); l.gonzalez@igme.es (L.M.); arubio@geol.uniovi.es (A.R.); acuesta@geol.uniovi.es (A.C.); gerdes@em.uni-frankfurt.de (A.G.)

Received: 2 October 2013 / Accepted: 5 May 2014 / Available online: 25 June 2014

\begin{abstract}
Late Palaeozoic conglomerate formations (Del Ratón and El Planchón) from the Andean Precordillera (Argentina) were studied to unravel their age, composition and provenance. The conglomerates from the Del Ratón Formation are formed by igneous clasts of acid, intermediate and basic compositions (volcanic and plutonic). Laser Ablation (ICP-MS) zircon U-Pb study has yielded an age of $348 \pm 2$ Ma (late Tournaisian) for the crystallization of a granitic clast, interpreted as a maximum deposition age for the Del Ratón Formation. Geochemistry of these clasts (high LILE/HFSE and $\mathrm{La} / \mathrm{Yb}$ ratios, negative $\mathrm{Nb}$-Ta anomalies) suggests a calc-alkaline batholithic source, probably located along the Andean Frontal Cordillera currently to the west, where similar calc-alkaline igneous rocks have been described. The El Planchón Formation overlies the Del Ratón Formation and, in the studied conglomerates, there are only igneous clasts of mafic composition (volcanic/subvolcanic). These mafic clasts have a very similar petrography and geochemistry to the Late Ordovician mafic igneous rocks of the Western Precordillera (low LILE/HFSE and $\mathrm{La} / \mathrm{Yb}$ ratios, no negative Nb-Ta anomalies). Therefore we suggest that the El Planchón conglomerate clasts were probably delivered mainly from northern sources within the Precordillera terrane. This change in clast provenance is tentatively related to a shift in mountain uplift from the Frontal Cordillera (in the west) to the Precordillera (in the east) after the early Visean.
\end{abstract}

Keywords: Late Palaeozoic, conglomerates, igneous clasts, U-Pb ICP-MS geochronology, sedimentary provenance, Gondwana, Andes

Resumen

Las formaciones conglomeráticas del Paleozoico superior (Del Ratón y El Planchón) de la Precordillera Andina (Argentina) fueron estudiadas con el fin de determinar su edad, composición y procedencia. Los conglomerados de la Formación Del Ratón están constituidos por clastos de rocas ígneas (volcánicas y plutónicas) ácidas, intermedias y básicas. Un estudio en circones con espectrometría de masas con plasma acoplado por inducción con ablación láser (LA-ICP-MS) proporciona una edad de $348 \pm 2$ Ma (Tournaisiense superior) para la cristalización de un clasto granítico, que interpretamos como la máxima edad del depósito de la Formación Del Ratón. La geoquímica de los clastos (altas relaciones LILE/HFSE y La/Yb, anomalías negativas de $\mathrm{Nb}$ - Ta) sugiere que probablemente derivan de batolitos calcoalcalinos descritos en algunos sectores de la Cordillera Frontal Andina localizada actualmente al oeste. La Formación El Planchón se superpone a la Formación Del Ratón y los clastos estudiados en los conglomerados de esta formación son únicamente de rocas ígneas básicas (subvolcánicas/volcánicas). Estos clastos tienen una petrografía y geoquímica similar a las rocas ígneas máficas del Ordovícico Superior de la Precordillera Occidental (bajas relaciones LILE/HFSE y La/Yb, ausencia de anomalías negativas en Nb-Ta). Por ello nosotros sugerimos que los clastos de los conglomerados de la Formación El Planchón proceden de materiales localizados al norte dentro de la propia Precordillera. Este cambio en la procedencia de los clastos es tentativamente relacionado con una transferencia de la deformación desde la Cordillera Frontal (al oeste) a la Precordillera (al este), provocando el levantamiento de la Precordillera a partir del Viseense inferior.

Palabras clave: Paleozoico superior, conglomerados, clastos ígneos, geocronología U-Pb ICP-MS, procedencia sedimentaria, Gondwana, Andes 


\section{Introduction and aims of this study}

In this work we investigate the age and origin (provenance) of late Palaeozoic conglomerate formations of central-western Argentina. Conglomerates are sediments closely related to source areas and frequently linked with tectonically active basin margins. The investigation of such rocks, when formed by igneous clasts, permits direct geochronology and petrology studies that help improve the stratigraphic knowledge and location of possible source areas by comparing igneous clasts with known igneous rocks nearby.

The late Palaeozoic sequences of central-western Argentina are the most complete stratigraphic record for this time in South America (Limarino and Spalletti, 2006; Astini et al., 2011). This is one of the few regions of Gondwana with a continuous fossil record from early Carboniferous to Permian, including abundant plant remains, palynomorphs and invertebrates, widely represented in the Río Blanco, Calingasta-Uspallata, San Rafael and Paganzo basins (Césari et al., 2011 and references therein). However, the age of these sequences established by palynofloras, macrofloras, and marine faunas remains under discussion in some areas due to the absence of species having worldwide biochronological value and the scarcity of radiometric ages (Césari et al., 2011).

Thick sequences of early Carboniferous rocks (Mississippian) crop out along the Western Argentine Precordillera (Fig. 1a, b). This stratigraphic interval is often poorly represented in West Gondwana (Limarino and Spalletti, 2006; Limarino et al., 2006). Within these sequences the Angualasto Group represents the remains of much larger deposits that once occupied most of the Río Blanco (to the north of study area) and Calingasta-Uspallata basins (Fig. 1b) (Limarino and Césari, 1993). In these arc-related basins, the early Carboniferous deposits are considered synorogenic sequences of the Chanic orogeny (Limarino and Spalletti, 2006; Limarino et al., 2006; Heredia et al., 2012; Limarino et al., 2012). This Late Devonian-early Carboniferous orogeny has been ascribed to the docking of the Chilenia terrane to southwestern Gondwana margin, formed by the previously accreted Cuyania terrane (Fig. 1a) (Ramos, 1988).

The Angualasto Group, defined by Limarino and Césari (1993), includes the Malimán and Cortaderas formations in the Río Blanco basin, north of the Río Jáchal, and the Del Ratón Formation in the Calingasta-Uspallata basin, outcropping in the vicinity of the Río San Juan within the study area (Fig. 1b). The Del Ratón Formation is stratigraphically equivalent (Sessarego and Césari, 1986) or partially equivalent (Azcuy et al., 2000) to the Malimán Formation. The age attributed to the Malimán Formation and equivalent units, from invertebrates and palaeoflora, is late Tournaisian-early Visean; the Cortaderas Formation is late Visean, based on palynomorphs (references in Césari et al., 2011).

Despite the importance of these deposits, the age and stratigraphic relationships between the Del Ratón Formation and other late Palaeozoic units, El Planchón and Del Salto formations, is very controversial. In this work we provide a U-Pb zircon age from an igneous clast in the conglomeratic lower section of the Del Ratón Formation, which establishes the maximum age of deposition, thus confirming the fossilbased age previously assigned to this formation and the start of synorogenic deposits of the Chanic orogeny in this region. We also undertake a detailed geochemical study of igneous clasts from conglomerates of the Del Ratón and El Planchón formations and compare them with known igneous complexes. This provenance study indicates substantial source differences between these formations.

\section{Geological framework}

\subsection{General overview}

The Argentine Precordillera forms the northern part of Cuyania, one of the larger terranes accreted to the southwestern Gondwana margin during the Palaeozoic (Ramos et al., 1986) (Fig. 1a). This terrane has been the focus of intense research to unravel its palaeogeographic links usually interpreted in terms of its accretion to southwestern margin of Gondwana (1, in Fig. 1a) in early Palaeozoic times (Ramos et al., 1986; Ramos, 1988; Astini et al., 1995; Dalziel, 1997; Thomas et al., 2002; Thomas and Astini, 2003; Finney, 2007) and the later accretion of the Chilenia terrane against it ( 2 , in Fig. 1a) in Late Devonian-early Carboniferous times (Ramos et al., 1984, 1986).

The Argentine Precordillera is a fold-and-thrust belt (Baldis and Chebli, 1969; Limarino et al., 2006; Limarino and Spalletti, 2006; Alonso et al., 2008; Ramos and Folguera, 2009; among others) about $80 \mathrm{~km}$ wide (Fig. 1b) formed by Palaeozoic and Tertiary sediments (Bracaccini, 1946; Heim, 1952), that according to stratigraphic and structural features, has been divided into Western, Central and Eastern domains (Fig. 1b). The Eastern and Central Precordillera represent a stable carbonate platform during Cambrian and Early Ordovician (Bordonaro, 1999). The Western Precordillera is characterised by Cambrian-Ordovician olistostrome or mélange deposits related to extensional tectonics in a continent-ocean transition (Astini, 1997; Keller, 1999), and ocean floor-like sediments with pillow basalts in the westernmost part (Kay et al., 1984), indicating the existence of an ancient continental margin (e.g. Spalletti et al., 1989; Astini, 1997; Keller, 1999). This early Palaeozoic continental margin (2, in Fig. 1a) was affected by extension during Ordovician and remained stable until the Late Devonian (Alonso et al., 2008). Subsequently, the accretion of the Chilenia terrane against the western Cuyania margin generated the Late Devonian-early Carboniferous Chanic tectonic phase of the Famatinian orogenic cycle (Ramos et al., 1984, 1986) or Chanic orogeny (Heredia et al., 2012). This collision resulted in a complex deformation and low-grade metamorphism that affected mainly pre-Car- 

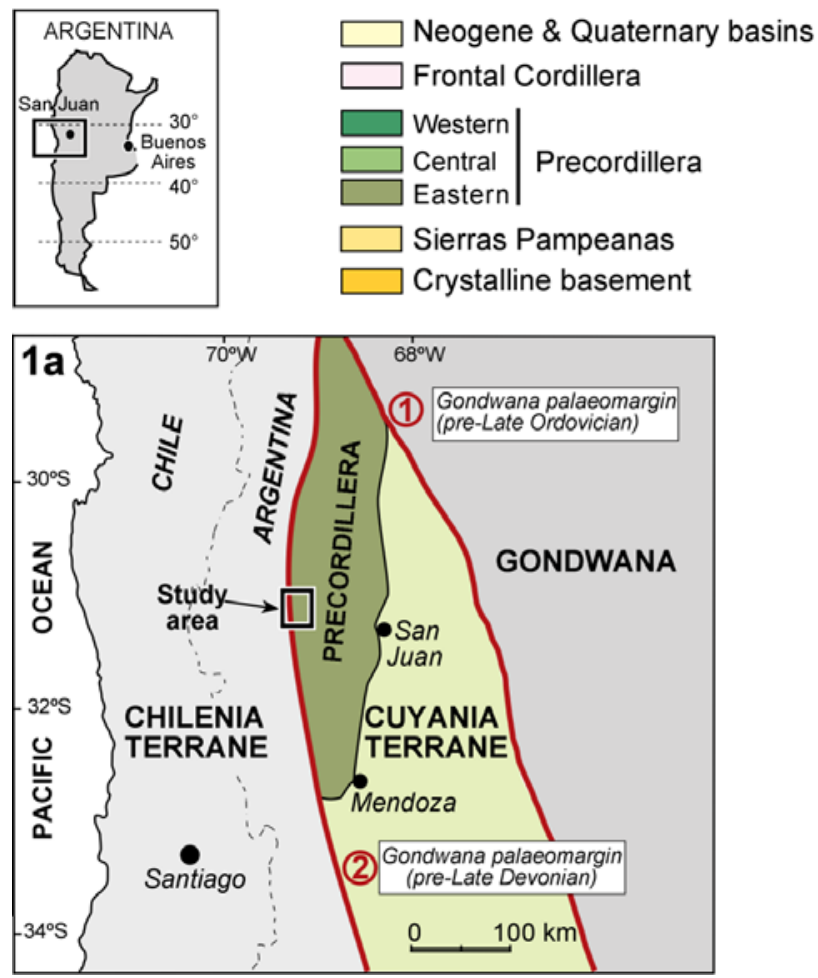

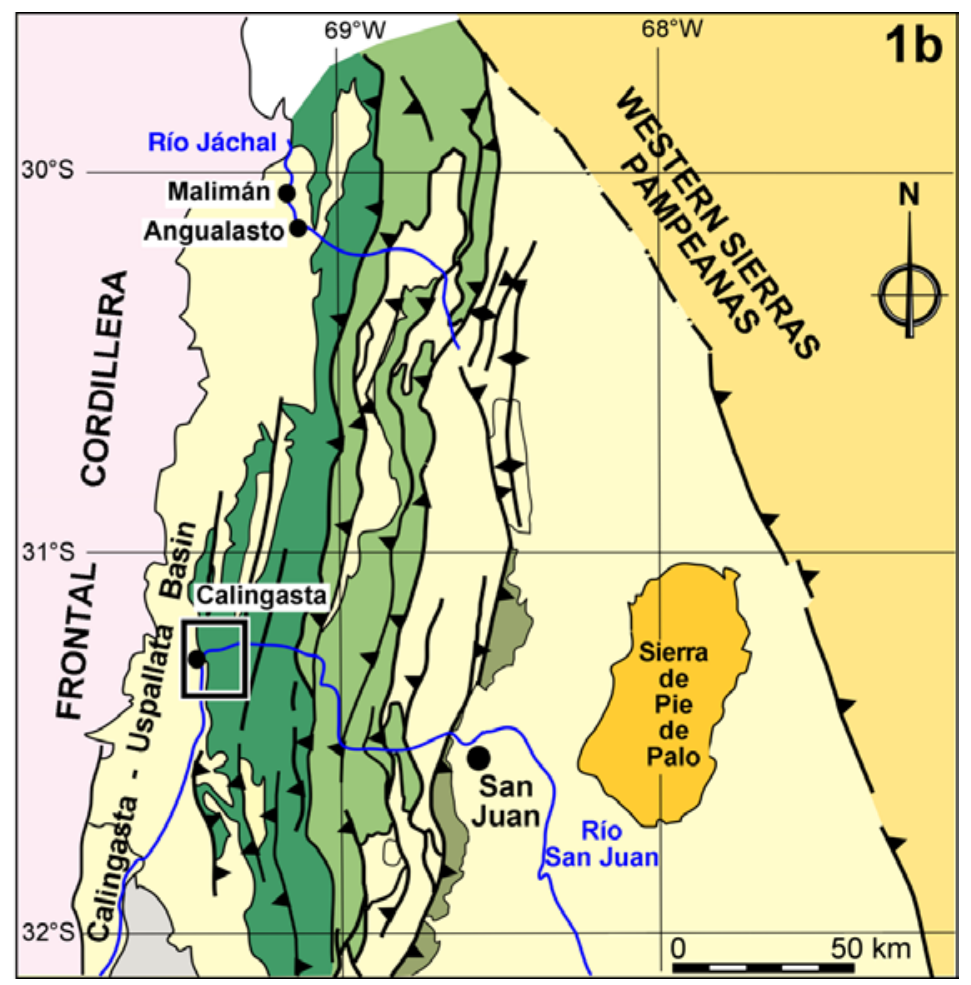

Fig. 1.- a) Terranes of the Central Andes basement and location of the study area. b) Geological domains of the Argentine Precordillera (modified from Alonso et al., 2008) showing the zone of the present study in the Western Precordillera. boniferous rocks (Furque, 1979) of the Western Precordillera (Keller et al., 1993; Gosen, 1997; Davis et al., 2000). Chanic synorogenic deposits of the early Carboniferous Angualasto Group (Limarino and Césari, 1993) in Western Precordillera overlie folded and cleaved rocks of Devonian age with a strong angular unconformity (Azcuy et al., 1981; Limarino and Césari, 1993; López Gamundi and Rossello, 1993; Alonso et al., 2008; Amenábar and di Pasquo, 2008; Colombo et al., 2012; among others).

\subsection{Stratigraphic relations of the late Palaeozoic formations in the studied area.}

South of the Río San Juan (Fig. 2), Devonian rocks consist of a sequence of sandstones and shales denominated Codo Formation (Guerstein et al., 1965; Sessarego, 1988) unconformably underlying the Del Ratón Formation (Azcuy et al., 1981; López Gamundi and Rossello, 1993) of Angualasto Group (Limarino and Césari, 1993). The Codo Formation has been tentatively dated as Givetian-Frasnian according its palynological assemblage (Amenábar and di Pascuo, 2008). The Del Ratón Formation (Guerstein et al., 1965; Quartino et al., 1971) is a conglomeratic unit with subordinate sandstones and shales, divided in two cycles (De Rosa, 1983), three members (Sessarego and Césari, 1988), and recently in two sections (Colombo et al., 2012). A fact highlighted by different authors is the presence of up to $60 \%$ of igneous clasts in the conglomerates of this formation (Quartino et al., 1971; De Rosa, 1983; Tófalo et al., 1985; Sessarego et al., 1990), including granites, quartz monzonites, quartz syenites, syenites, rhyolites, rhyodacites and basaltic rocks (Sessarego et al., 1990). According to Colombo et al. (2012), the erosive surface over the Codo Formation is marked by a pavement of disordered and heterometric $(30-50 \mathrm{~cm})$ granitic clasts. Over this pavement, within the lower section, there are various metric conglomeratic layers with rounded or subrounded clasts of 3-5 cm in size, of whitish granites (70\%), metamorphic rocks (20\%) and sedimentary rocks (10\%). Alternating with these conglomerates appear layers with clasts sizes of 30-40 cm. In the upper section, and above an erosive discordance, matrix-supported reddish conglomerates include clasts of sandstones and greywacke (65\%), pinkish granites and rhyolites (30\%), quartz and metamorphic rocks $(5 \%)$. In this upper section there are also disordered and poorly sorted conglomerates with very coarse clasts $(40-50 \mathrm{~cm})$ of reddish granites and rhyolites. The age assigned to the Del Ratón Formation is Tournaisian-Visean, based on fossiliferous assemblages (Scalabrini Ortiz, 1973; Sessarego and Césari, 1988; Césari and Gutiérrez, 2001), or early Visean from palynological data (Amenábar and di Pascuo, 2008).

Other late Palaeozoic deposits cropping out south of the Río San Juan are the El Planchón and Del Salto formations (Fig. 2). The El Planchón Formation (Quartino et al., 1971; Sessarego, 1983, 1988) consists of shales and sandstones which grade laterally into conglomerates (Colombo et al., 2012). Its stratigraphic relationships with the Del Ratón and 
Del Salto formations are very controversial and the age remains undetermined because the El Planchón Formation is palynologically barren (Amenábar and Di Pascuo, 2008). Some authors proposed a Devonian age based on marine fossils (Kerlleñevich, 1967), suggesting that it would be stratigraphically below the Del Ratón Formation (Sessarego, 1983) or in fault contact with it (Amenábar and Di Pascuo, 2008). Others consider that the El Planchón Formation rests unconformably over the Del Ratón Formation and constitutes the lower part of the Del Salto Formation (Quartino et al., 1971; Alonso et al., 2005). However according to Colombo et al. (2012), the El Planchón Formation is overlain unconformably by the Del Salto Formation (Fig. 2). The age proposed for the Del Salto Formation is late Carboniferous (Pennsylvanian)-early Permian based on marine fossils (Azcuy et al., 2007). The Del Salto Formation represents the synorogenic sequences of late Carboniferous-early Permian Gondwanan orogeny (Colombo et al., 2012). Pre-orogenic late Carboniferous (Pennsylvanian) deposits related to this orogeny are absent in this area, and in most of the Western Precordillera. The absence of most late Carboniferous sediment record is explained because the pre-Precordillera (ProtoPrecordillera) probably formed a horst-like topographic high inherited from the Chanic cordillera (Limarino and Spalletti, 2006; Heredia et al., 2012). Therefore, the El Planchón conglomerate Formation could belong to the early Carboniferous (Mississippian) deposits of Angualasto Group synorogenic with the Late Devonian-early Carboniferous Chanic orogeny.

\section{Samples and analytical techniques}

For this study a set of 36 samples were collected south of the Río San Juan, between the 114 and 118 km markers on the RN 20 road, near of Calingasta (Fig. 2). Most of the samples (31) correspond to igneous clasts from the conglomerates of the Del Ratón Formation cropping out at the Quebrada Km 117 valley. In this formation we have studied two different conglomerate layers. One of these is a disordered and poorly sorted boulder conglomerate formed by very coarse clasts (up to $30-50 \mathrm{~cm}$ ) of reddish or pinkish acid-intermediate igneous rocks, and smaller dark-coloured clasts of basic igneous rocks (Fig. 3a). The other conglomerate layer studied in this formation, and located above, is a poorly sorted cobblepebble conglomerate formed by clasts smaller than $15 \mathrm{~cm}$ within a micro-conglomeratic matrix. Clasts are of whitish acid-intermediate igneous rocks, basic igneous rocks, and in smaller proportion, of sedimentary and metamorphic rocks (Fig. 3b). For comparative purposes, we also collected 5 representative samples in a conglomerate layer from the upper part of the El Planchón Formation, at the Quebrada del Salto valley (Fig. 2). This conglomeratic layer is 2 metres thick, poorly sorted, formed by clasts up to $15 \mathrm{~cm}$ within a sandmudstone matrix. All the clasts are dark-coloured mafic igneous rocks.

\subsection{Major and trace element analyses}

From the total sample set, 17 representative igneous clasts (boulders) were selected for major and trace element analyses. Major and some trace elements ( $\mathrm{V}$ to $\mathrm{Pb}$ ) were analysed by $\mathrm{X}$ ray fluorescence (XRF) in the Technical-Scientific Services of Oviedo University (Spain) using a WD-XRF spectrometer (model 2404; PANalytical) coupled with a $\mathrm{Rh}$ tube. Major element analyses were performed using glass beads of powdered rocks after fusion with lithium tetraborate. Precision of the XRF technique was better than $\pm 1 \%$ relative. Trace elements were determined on pressed pellets with Elvacite. Raw data were processed using Pro-Trace-XRF PANalytical software. Other trace elements (U, Th, Hf, Ta) and rare earth elements (REE) were analysed by inductively coupled plasma mass spectrometry (ICP-MS) following sample decomposition with lithium metaborate at the Geochronology and Geochemistry-SGIker facility of El País Vasco University/EHU (Spain) (see García de Madinabeitia et al., 2008 for additional details).

\subsection{U-Pb ICP-MS isotopic analyses}

An igneous clast of the lower conglomerates layers from the Del Ratón Formation (sample AN47) was processed for zircon separation and $\mathrm{U}-\mathrm{Pb}$ geochronology. Rock pulverization and mineral separation using a Wilfley table, heavy liquids, and a Frantz isodynamic separator were performed at University of Oviedo (Spain). The selected zircon fractions were hand picked under a binocular microscope. The zircon mount was prepared using double-sided tape, a plexiglass ring, and Buehler Epoxicure resin. BSE and CL images of the individual grains were obtained with the Cameca SX100 electron microprobe of Oviedo University to assess the internal morphology before carrying out the U-Pb laser work.

Zircon U-Pb analyses were carried out at Johann Wolfgang Goethe-University Frankfurt/JWG (Germany) using a Thermo-Finnigan Element II SF-ICP-MS coupled to a New Wave UP213 ultraviolet laser system. Laser spot-sizes varied from 20 to $40 \mu \mathrm{m}$ for zircon. The typical depth of the ablation crater was $\sim 20 \mu \mathrm{m}$. Data were acquired in peak-jumping mode over 900 mass scans during $20 \mathrm{~s}$ background measurement followed by 32 second sample ablation. A teardrop-shaped, low volume laser cell was used to enable the precise detection of heterogeneous material (e.g., inclusions or different growth zones) during time resolved data acquisition (see Janousek et al., 2006).

Laser-induced elemental fractionation and instrumental mass discrimination were corrected by normalization to the reference zircon GJ-1 (Jackson et al., 2004). Prior to this normalization, the change of elemental fractionation (e.g., the $\mathrm{Pb} / \mathrm{Th}$ and $\mathrm{Pb} / \mathrm{U}$ ratios as a function of ablation time and thus crater depth) was corrected for each set of isotope ratios (c. 40 ) collected during the time of each single spot analysis. The 

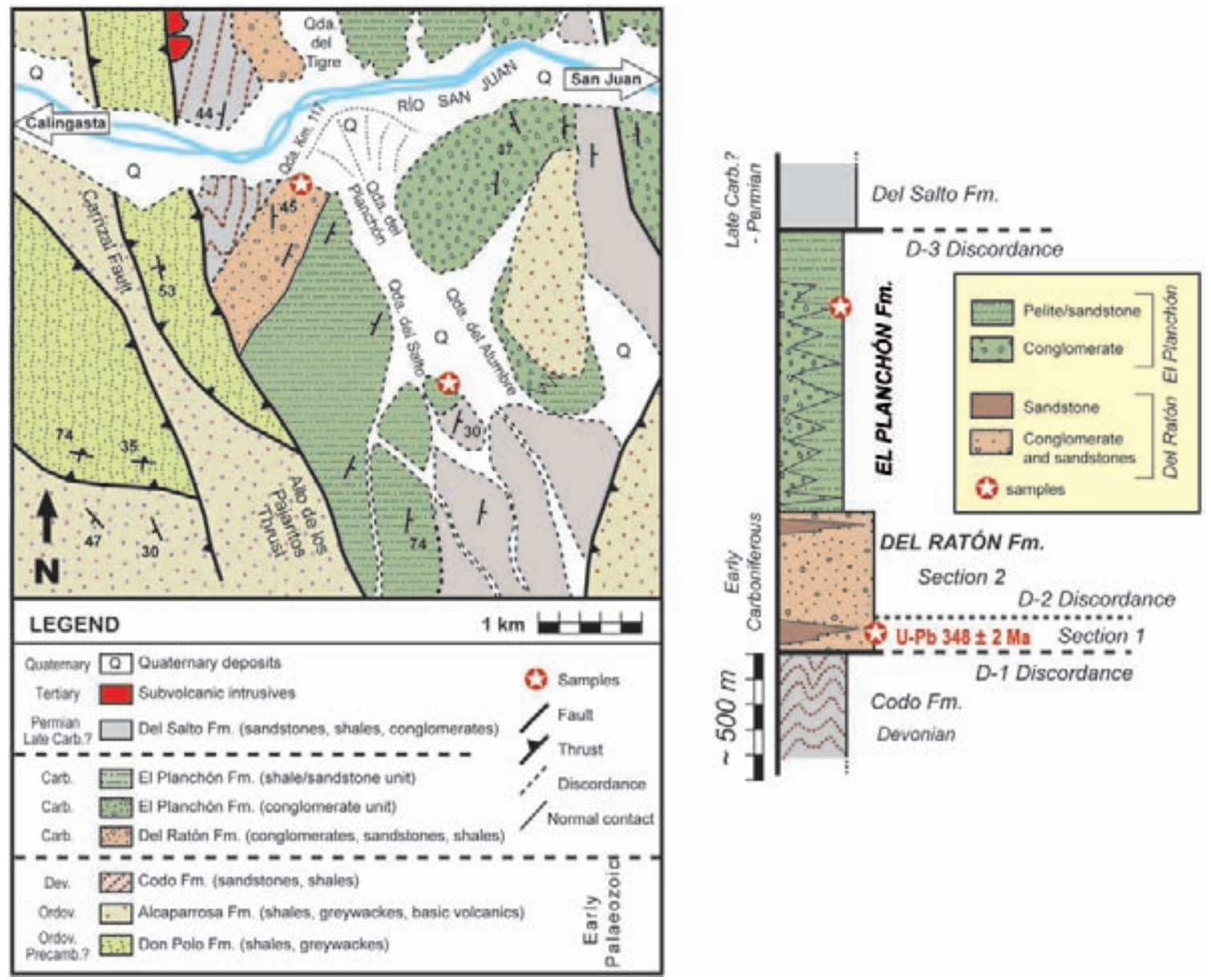

Fig. 2.- Simplified geological map of study area (after Alonso et al., 2008 and Amenábar and di Pascuo, 2008) and schematic stratigraphic section of the Del Ratón and El Planchón formations, based on Colombo et al. (2012), with the location of sampled sites.
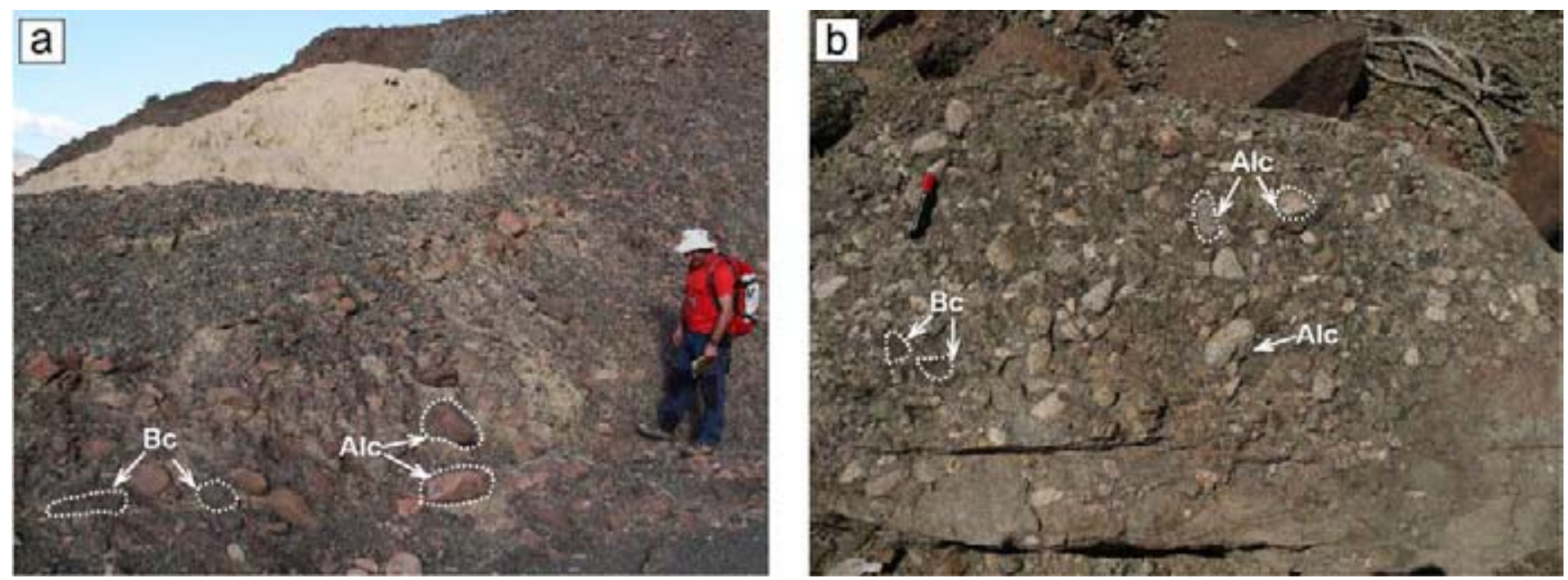

Fig. 3.- Field appearance of the Del Ratón Formation conglomerates at the Quebrada Km 117 valley. a) Conglomerate consisting mainly of large clasts of reddish-coloured acid-intermediate igneous rocks (AIc) and dark-coloured basic igneous rocks (Bc). b) Conglomerate formed by clasts, smaller than $15 \mathrm{~cm}$, of acid-intermediate (AIc) and basic igneous rocks (Bc).

correction was done by applying a linear regression through all measured ratios. The total offset of the measured driftcorrected ${ }^{206} \mathrm{~Pb} /{ }^{238} \mathrm{U}$ ratio from the "true" ID-TIMS value of the analysed GJ-1 grain was about 3-4\%. Reported uncer- tainties $(2 \sigma)$ were propagated by quadratic addition of the external reproducibility ( 2 s.d.) obtained from the standard zircon GJ-1 $\left(\mathrm{n}=20 ; 1.3 \%\right.$ and $1.2 \%$ for the ${ }^{207} \mathrm{~Pb} /{ }^{206} \mathrm{~Pb}$ and ${ }^{206} \mathrm{~Pb} /{ }^{238} \mathrm{U}$, respectively) during the analytical session and the 
within-run precision of each analysis (2 s.e.). For further details on analytical protocol and data processing for the $\mathrm{U}-\mathrm{Pb}$ method see Gerdes and Zeh $(2006,2009)$.

\section{Petrography}

A set of 36 thin sections of igneous clasts from the conglomerate layers of the Del Ratón and El Planchón formations were studied. The petrographic classification of the igneous clasts is just an approximation because it is impossible to know if they were part of plutonic, subvolcanic or volcanic igneous complexes. The main petrographic features of individual clasts are summarised in Table 1.

\subsection{Boulder conglomerate from the Del Ratón Formation.}

In this conglomerate (Fig. 3a), the studied clasts are plutonic and volcanic rocks, ranging in composition from acid to basic, although acid-intermediate compositions are prevalent. Samples were divided in two main groups: i) plutonic -volcanic rocks and ii) pyroclastic rocks. In most of the cases, but especially in the rocks of intermediate to acid composition, the rocks show moderate to severe hydrothermal alteration, with the development of potassic minerals (sericite, K-feldspar), prehnite, and carbonates accompanied by other secondary minerals (epidote, quartz, chlorite, titanite).

i) Plutonic-volcanic rocks. This group includes a wide variety of rocks ranging from gabbros and basalts to granites and rhyolites.

Gabbros. These are the least abundant rocks. Their texture is coarse- to medium-grained, porphyritic to ophitic and subophitic, with a doleritic matrix. The mineral assemblage includes clinopyroxene, plagioclase, opaque minerals, and smectites (probably pseudomorphs after olivine). Clinopyroxene is the most abundant phase (Fig. 4a), and constitutes phenocrysts in the porphyritic rocks, with sizes up to $4 \mathrm{~mm}$.

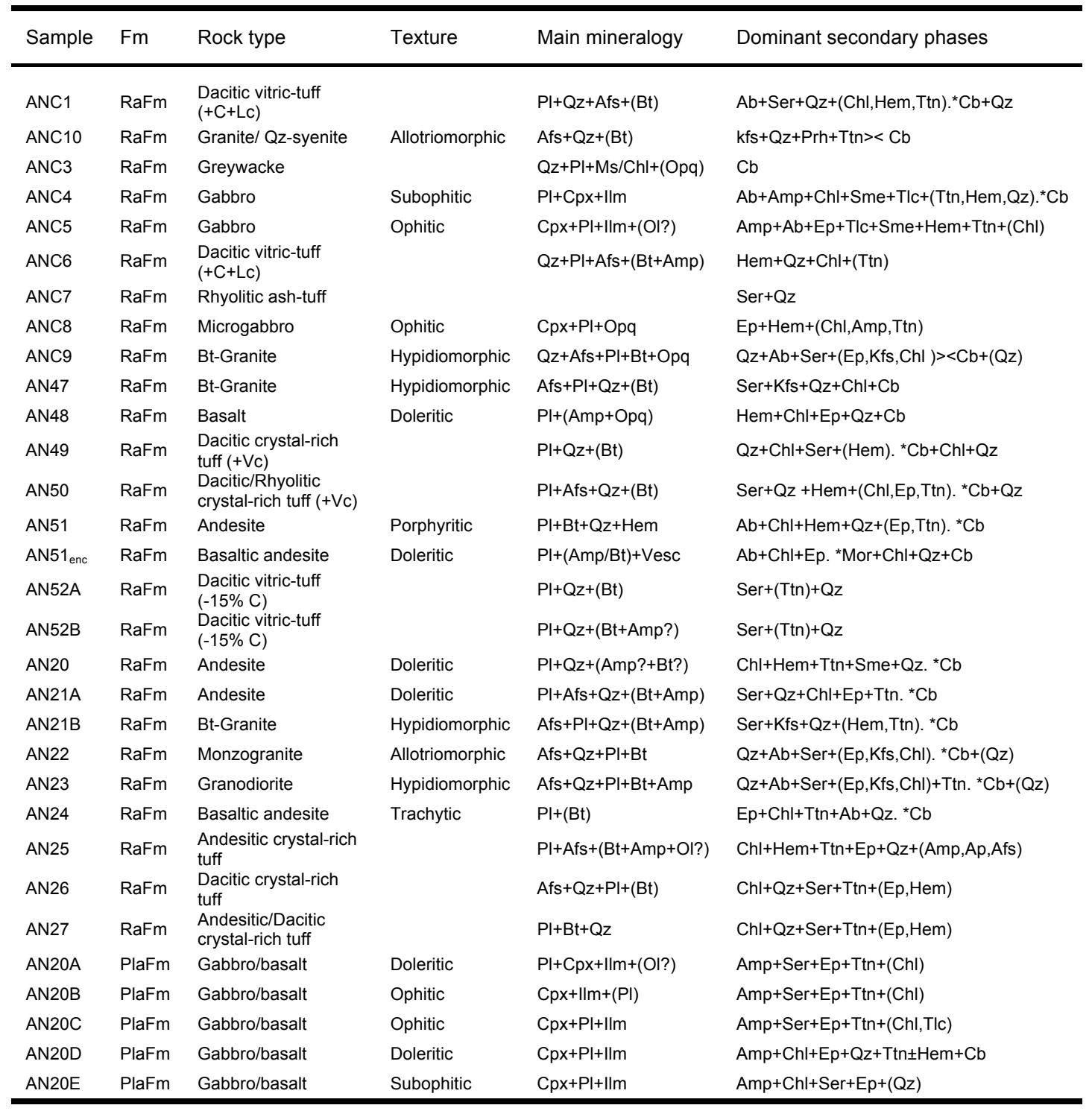

C: Crystals. Lc: Lithic clasts. Vc: Vitriclasts. Enc: Enclave. In parentheses: minerals in very low \%. $\left(^{\star}\right)$ : Minerals related with a later alteration

Table 1.- Main petrographic features of the igneous clasts from the Del Ratón (RaFm) and El Planchón (PlaFm) conglomerate formations. 

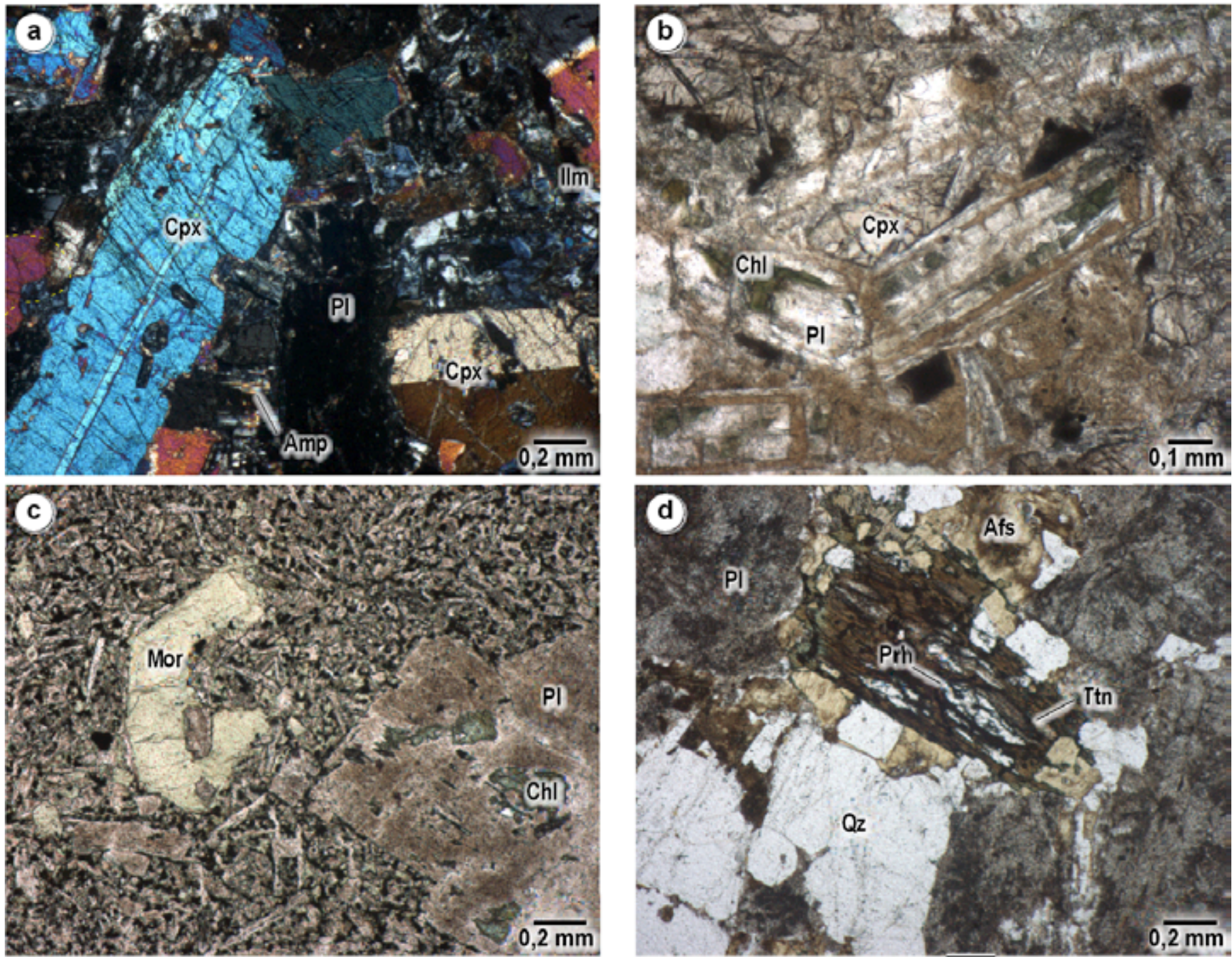

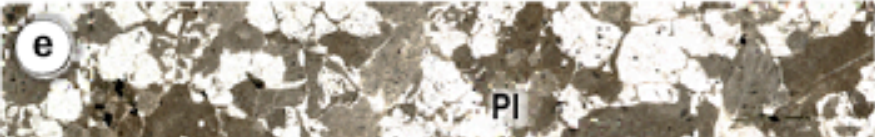

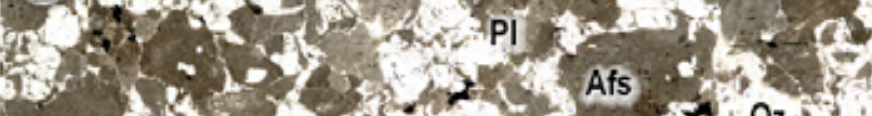
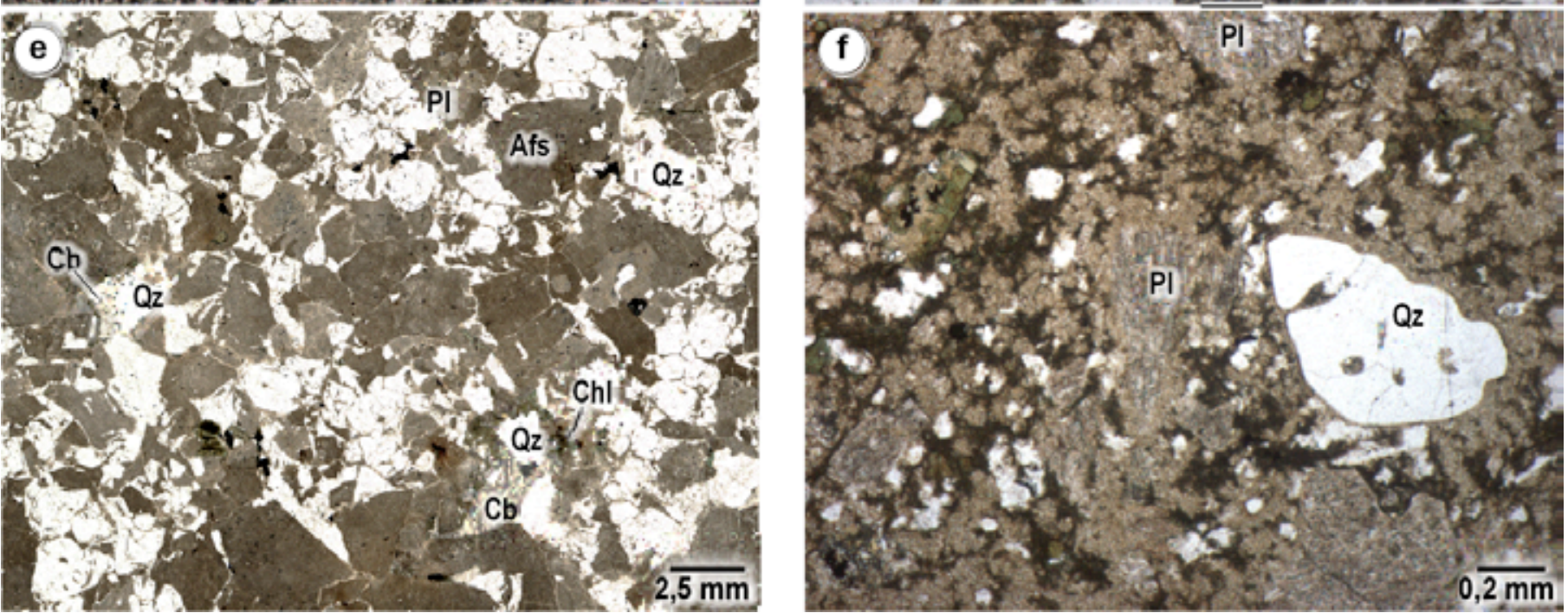

Fig. 4.- Photomicrographs showing the petrography of large igneous clasts (up 30-50 cm) from the conglomerates of the Del Ratón Formation. a) Texture of Cpx-rich gabbro. b) Altered gabbro, with development of Chl and Mor (brown colour). c) Moderately altered andesite. It shows Mor totally replacing previous mafic minerals and development of $\mathrm{Ab}+\mathrm{Chl}+\mathrm{Hem}$. d) Granite with partially altered Bt to Chl (+Prh+Ttn). e) Texture of the granite sample selected for U-Pb zircon analyses (AN47), showing pervasive silicification. f) Crystal-rich tuff of rhyolitic composition, showing a vitreous matrix with spherulitic and perlitic textures. Mineral abbreviations (Whitney and Evans, 2010): Cpx (clinopyroxene), Amp (amphibole), Pl (plagioclase), Ilm (ilmenite), Chl (chlorite), Mor (mordenite), Qz (quartz), Afs (alkali feldspar), Ttn (titanite), Prh (prehnite), $\mathrm{Cb}$ (carbonate), Hem (hematite), Ab (albite), Bt (biotite). 
All these rocks show a moderate hydrothermal alteration that produced chlorite, smectites (mordenite), talc, titanite, actinolite, albite, quartz, and carbonates (Fig. 4b).

Basalts and basalt andesites. These are equigranular rocks, mainly with doleritic textures but in some cases with microlithic or fluidal microlithic textures. Their mineralogy is formed by plagioclase, amphibole, and biotite. The samples show a moderate hydrothermal alteration, with nearly complete replacement of mafic minerals by a secondary paragenesis dominated by chlorite and epidote, with hematite, quartz, and carbonates. One sample of basaltic andesite presents vugs larger than $3 \mathrm{~mm}$ filled by mordenite, chlorite, quartz, and carbonates.

Andesites. These are porphyritic and hypocrystalline rocks that occasionally host basic enclaves. The mineral assemblage is formed by plagioclase, biotite, quartz, and hematite. Plagioclase phenocrysts are larger than $8 \mathrm{~mm}$ and form $>40 \%$ of the rock (Fig. 4c). The groundmass is altered and replaced by a granoblastic mixture of quartz, plagioclase, and hematite, with grain sizes below $0.1 \mathrm{~mm}$. The hydrothermal paragenesis of these rocks includes-chlorite, mordenite, albite, hematite, quartz, and carbonates, with minor epidote and titanite. Some of these minerals represent pseudomorphs after previous mafic minerals (Fig. 4c).

Granites. There are several samples of granitic clasts whose composition varies from quartz-syenites (alkali feldspar rich) to biotite-amphibole granodiorites and biotitic monzogranites. These rocks have pinkish to reddish colours, indicating hydrothermal alteration. The mineral assemblage includes K-feldspar, quartz, plagioclase, altered biotite, \pm amphibole (Fig. 4d). The texture is medium to coarse-grained hypidiomorphic or allotriomorphic (2-10 mm crystal size). An important potassic alteration generated $\mathrm{K}$-feldspar overgrowths and a decrease of quartz content. Other secondary minerals are carbonate, sericite, prehnite, titanite, chlorite, and minor epidote and hematite. In some samples is possible to recognize a sequence of alteration events. Initially, the rock developed pervasive potassic alteration where plagioclase was partially replaced by $\mathrm{K}$-feldspar. This potassic alteration stage also produced quartz leaching, biotite replacement by chlorite ( \pm prehnite, \pm titanite), and concentration of accessory minerals such as zircon and monazite. In a second stage, the rock underwent a process of light to moderate silicification (Fig. 4e); this produced re-precipitation of euhedral quartz filling voids. There is also evidence of infiltration and precipitation of feldspar in cracks and crystallization of chlorite and mordenite, covering the interior of the previous voids. Finally, a stage of carbonatization affected the rock, with the partial replacement of feldspar by calcite, and a complete fill of previous voids.

ii) Pyroclastic rocks. This group is formed by rocks whose composition ranges from andesite to rhyolite. Different textures are observed, from crystal-rich tuffs to vitriclastic tuffs.

Andesitic tuffs. This group includes a great diversity of textures and mineral assemblages. It varies from crystal- rich tuffs $(20-70 \%$ of crystals) to vitreous-rich tuffs $(>30 \%$ of vitriclasts) of andesitic composition. Crystals are mainly plagioclase, quartz, \pm biotite. In some samples K-feldspar, amphibole or pseudomorphs of mafic minerals (probably olivine) were observed. All these rocks were affected by low to severe hydrothermal alteration that generated albite, sericite and quartz, with minor titanite, hematite, chlorite, and epidote \pm carbonates.

Dacite-Rhyolite tuffs. These rocks are mainly crystal-rich tuffs, with K-feldspar, quartz, and minor plagioclase, biotite or amphibole. Lithic clasts are less abundant and are similar in mineralogy to the host rock. The groundmass was replaced by a granoblastic aggregate of quartz, sericite, and opaque minerals, but it is still possible to recognize ghosts of devitrification textures, such as perlitic, spherulitic and patchy structures or sintaxial growths over the crystals (Fig. 4f). Scarce samples of vitreous-tuffs occur, including microcrystalline sericite-quartz cineritic clasts.

\subsection{Cobble-pebble conglomerate from the Del Ratón Formation.}

This conglomerate layer (Fig. 3b) is composed by clasts very similar in texture and composition to those in the conglomeratic unit described above. The samples selected correspond mainly to the micro-conglomeratic matrix between large clasts $(<15 \mathrm{~cm})$. The same two groups of rocks described above also occur in this unit (plutonic-volcanic and volcaniclastic). The most abundant clasts are crystal-rich and vitreous-rich tuffs of light brown colour (Fig. 5a, b), with variable phenocrysts content, and evidence of glass hydration (devitrification) textures (perlitic, spherulitic, patchy textures, etc.). Less abundant, granitic and basaltic clasts (Fig. $5 \mathrm{c}, \mathrm{d})$ have textures, composition, and hydrothermal alteration similar to those described in the previous unit.

\subsection{Cobble conglomerate from the El Planchón Formation.}

In this conglomeratic layer one type of igneous clasts was found. These are gabbros/basalts, with different proportions of clinopyroxene, plagioclase, \pm ilmenite, affected by hydrothermal alteration. All the clasts are dark-coloured and coarse-grained equigranular to porphyritic, although doleritic, ophitic and sometimes subophitic textures are observed (Fig. 5e, f). The phenocrysts of plagioclase or clinopyroxene are larger than $4 \mathrm{~mm}$ of long, while the groundmass is finegrained and less than $0.8 \mathrm{~mm}$. The studied samples record light to moderate hydrothermal alteration that generated amphibole, sericite, epidote, hematite, titanite, and in some cases talc, quartz, and carbonates.

\section{U-Pb zircon age of the Del Ratón Formation}

A representative igneous clast sample $(\approx 50 \mathrm{~cm}$ in size $)$ was selected for $\mathrm{U}-\mathrm{Pb}$ isotopic analyses. This is a pinkish 

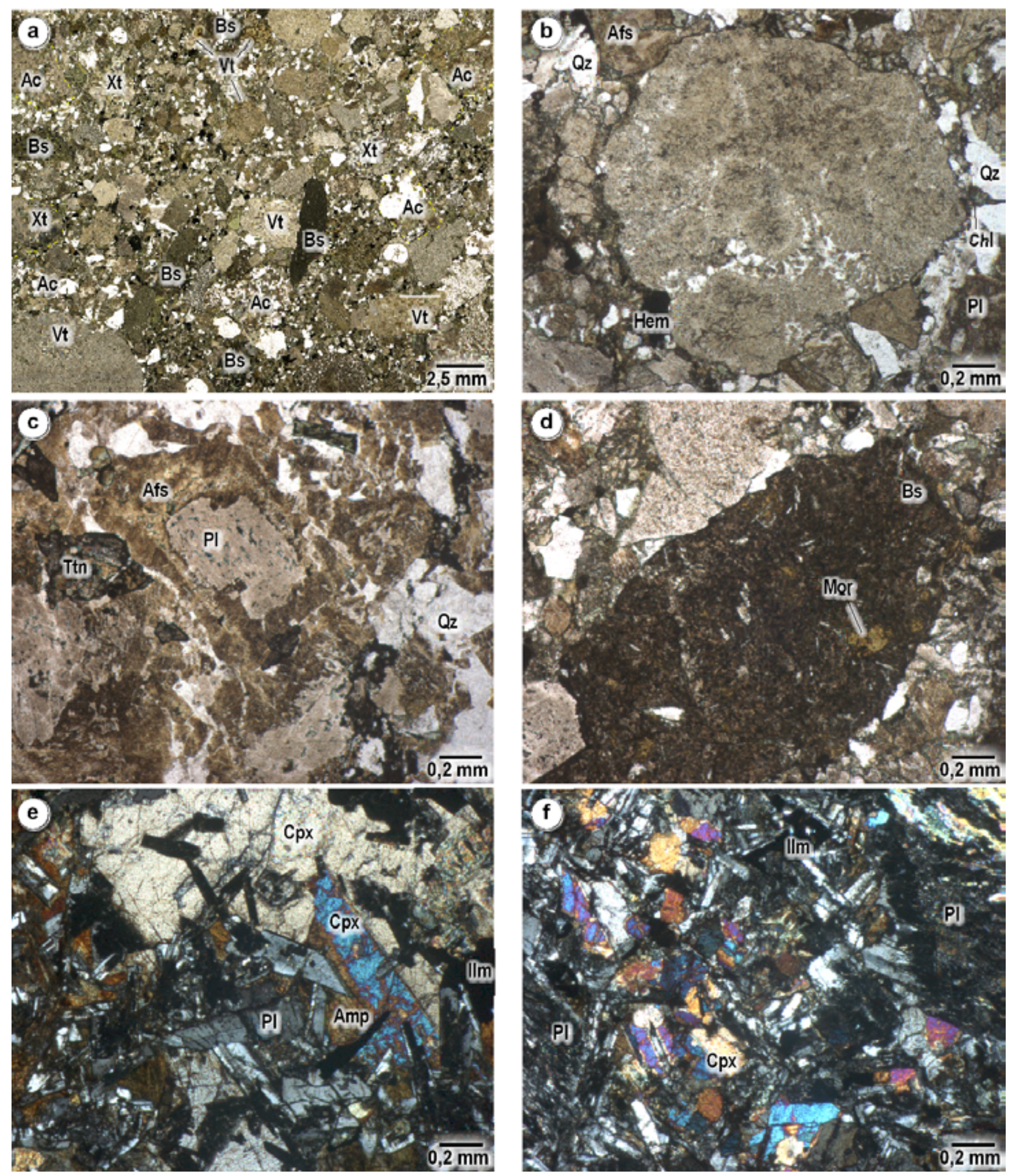

Fig. 5.- Petrography of the matrix from conglomerates of clasts $<15 \mathrm{~cm}$ of the Del Ratón Formation (a-d), and clasts from the El Planchón conglomerate (e-f). a) Micro-conglomerate matrix formed by basalt and gabbro clasts (Bs), vitreous-rich tuff (Vt), crystal-rich tuff (Xt), and granites (Ac). b) Clast of vitreous-rich tuff with spherulitic texture and incipient silicification. c) Granite clast with potassic alteration. d) Basaltic clast with pervasive alteration assemblage that includes Mor, Ab and Hem. e) Gabbro/basalt clast with subophitic texture. f) Doleritic texture in the matrix of a porphyritic gabbro/basalt clast, with phenocrystals of partially altered Pl. Mineral abbreviations as in figure 4. 
coloured medium- to coarse-grained holocrystalline rock of granitic composition (sample AN47), with a moderate hydrothermal alteration (Fig. 4e). Its mineralogy is composed by $\mathrm{K}$-feldspar, plagioclase, and quartz, with minor biotite (replaced by chlorite \pm prehnite \pm titanite). Its textural features are dominated by secondary processes, with pervasive potassic alteration and less important carbonatization that are superimposed on the previous granitic texture (see Table 1).

In this study 29 isotopic analyses were obtained from 28 magmatic zircons (Table 2). The backscattered electron (BSE) images taken with electron microprobe show that the zircons are euhedral to subhedral short-prismatic crystals, with rhythmic concentric growth zoning parallel to crystal outlines (Fig. 6). Prior to isotopic analyses, zircons were classified following the method of Pupin and Turco (1972). These zircons fall into the S8 to L5 morphologies, mainly S4-S5, characteristic of rocks crystallized at low temperature $\left(650-700{ }^{\circ} \mathrm{C}\right)$. Of the 29 analyses, 27 provide a Concordia age of $348 \pm 2 \mathrm{Ma}$ that was interpreted as the crystallization age of the granite clast (Fig. 6). This places the granite crystallization very close to the Tournaisian-Visean boundary, established at 346.3 Ma in a global Carboniferous chronostratigraphic time scale (Davydov et al., 2010) or $347 \mathrm{Ma}$ in the Geological Time Scale (Walker et al., 2012). This age represents the maximum possible for deposition of the Del Ratón Formation that is bound to be just at the end of the
Tournaisian or more likely in the Visean, in agreement with palynological data (Amenábar and di Pascuo, 2008). This age also suggests that some of the granitic clasts incorporated into the Del Ratón Formation conglomerates come from the erosion of early Carboniferous igneous rocks related to Chanic magmatism.

\subsection{Comparison with ages from known igneous complexes}

Within the Precordillera, the existence of igneous rocks of early Carboniferous age is restricted to dykes recognised in the Devonian Codo Formation, to the north of study area (Sessarego et al., 1990). These authors describe dykes of granodiorites, diorites, quartz monzonites, trachytes, basalts, andesites, and rhyolites, with a Rb-Sr age of $337 \pm 10$ Ma, related to Chanic magmatic activity.

To the $\mathrm{E}$ and NE of the Precordillera, minor but widespread Devonian to early Carboniferous igneous rocks are present in the Sierras Pampeanas (Fig. 1b) (Dahlquist et al., 2006; Grosse et al., 2009; among many others). This early Carboniferous magmatism is represented by A-type granites and syenogranites, alkaline S-type granodiorites to granites, and alkaline I-type tonalites to granites (Dahlquist et al., 2010; Alasino et al., 2012 and references in both) generated during crustal extension (Grosse et al., 2009), with U-Pb ages of 350-323 Ma (references in Alasino et al., 2012). Further

\begin{tabular}{|c|c|c|c|c|c|c|c|c|c|c|c|c|c|c|c|c|c|c|c|c|c|c|c|}
\hline \multirow[b]{2}{*}{ grain } & \multirow[b]{2}{*}{ L-No. } & \multirow[b]{2}{*}{$\begin{array}{r}{ }^{207} \mathrm{~Pb}^{\mathrm{a}} \\
(\mathrm{cps}) \\
\end{array}$} & \multirow[b]{2}{*}{$\begin{array}{c}\mathrm{U}^{\mathrm{b}} \\
(\mathrm{ppm})\end{array}$} & \multirow[b]{2}{*}{$\begin{array}{c}\mathrm{Pb}^{\mathrm{b}} \\
(\mathrm{ppm})\end{array}$} & \multirow[b]{2}{*}{$\frac{T h^{b}}{U}$} & \multirow[b]{2}{*}{$\frac{{ }^{206} \mathrm{~Pb}}{{ }^{204} \mathrm{~Pb}}$} & \multirow[b]{2}{*}{$\frac{{ }^{206} \mathrm{~Pb}^{\mathrm{C}}}{{ }^{238} \mathrm{U}}$} & \multirow[b]{2}{*}{$\begin{array}{l} \pm 2 \sigma \\
(\%) \\
\end{array}$} & \multirow[b]{2}{*}{$\frac{{ }^{207} \mathrm{~Pb}^{\mathrm{c}}}{{ }^{235} \mathrm{U}}$} & \multirow[b]{2}{*}{$\begin{array}{l} \pm 2 \sigma \\
(\%) \\
\end{array}$} & \multirow[b]{2}{*}{$\mathrm{Rho}^{\mathrm{d}}$} & \multirow[b]{2}{*}{$\frac{{ }^{208} \mathrm{~Pb}^{\mathrm{c}}}{{ }^{232} \mathrm{Th}}$} & \multirow[b]{2}{*}{$\begin{array}{l} \pm 2 \sigma \\
(\%) \\
\end{array}$} & \multirow[b]{2}{*}{$\frac{{ }^{207} \mathrm{~Pb}^{\mathrm{c}}}{{ }^{206} \mathrm{~Pb}}$} & \multirow[b]{2}{*}{$\begin{array}{l} \pm 2 \sigma \\
(\%) \\
\end{array}$} & \multicolumn{4}{|c|}{ Age $(\mathrm{Ma})$} & \multirow[b]{2}{*}{$\frac{{ }^{208} \mathrm{~Pb}}{{ }^{232} \mathrm{Th}}$} & \multirow[b]{2}{*}{$\begin{array}{l} \pm 2 \sigma \\
(\mathrm{Ma}) \\
\end{array}$} & \multirow[b]{2}{*}{$\frac{{ }^{207} \mathrm{~Pb}^{\mathrm{c}}}{{ }^{206} \mathrm{~Pb}}$} & \multirow[b]{2}{*}{$\begin{array}{l} \pm 2 \sigma \\
(\mathrm{Ma}) \\
\end{array}$} \\
\hline & & & & & & & & & & & & & & & & $\frac{{ }^{206} \mathrm{~Pb}}{{ }^{238} \mathrm{U}}$ & $\begin{array}{l} \pm 2 \sigma \\
(\mathrm{Ma}) \\
\end{array}$ & $\frac{{ }^{207} \mathrm{~Pb}}{{ }^{235} \mathrm{U}}$ & $\begin{array}{l} \pm 2 \sigma \\
(\mathrm{Ma}) \\
\end{array}$ & & & & \\
\hline 2 & a22 & 5287 & 282 & 19 & 1,81 & 6674 & 0,05806 & 1,8 & 0,4265 & 3,0 & 0,59 & 0,01765 & 1,8 & 0,05328 & 2,4 & 364 & 6 & 361 & 9 & 354 & 6 & 341 & 55 \\
\hline 3 & a23 & 943 & 53 & 3,3 & 0,83 & 4796 & 0,05530 & 2,1 & 0,4042 & 8,5 & 0,25 & 0,01685 & 5,0 & 0,05301 & 8,3 & 347 & 7 & 345 & 25 & 338 & 17 & 329 & 187 \\
\hline 4 & a24 & 2576 & 145 & 9,1 & 0,68 & 19678 & 0,05503 & 1,8 & 0,4061 & 3,4 & 0,53 & 0,01713 & 2,6 & 0,05352 & 2,9 & 345 & 6 & 346 & 10 & 343 & 9 & 351 & 66 \\
\hline 8 & $\mathrm{a} 25$ & 5418 & 301 & 19 & 1,41 & 3778 & 0,05493 & 2,1 & 0,4097 & 4,3 & 0,49 & 0,01709 & 2,7 & 0,05410 & 3,7 & 345 & 7 & 349 & 13 & 343 & 9 & 375 & 84 \\
\hline $9-1$ & $\mathrm{a} 26$ & 4256 & 244 & 15 & 0,80 & 6397 & 0,05539 & 1,8 & 0,3979 & 3,4 & 0,54 & 0,01752 & 2,2 & 0,05210 & 2,8 & 348 & 6 & 340 & 10 & 351 & 8 & 290 & 65 \\
\hline $9-2$ & $\mathrm{a} 27$ & 8486 & 465 & 30 & 0,92 & 10478 & 0,05619 & 1,9 & 0,4160 & 2,8 & 0,69 & 0,01752 & 2,0 & 0,05369 & 2,0 & 352 & 7 & 353 & 8 & 351 & 7 & 358 & 45 \\
\hline 11 & $\mathrm{a} 28$ & 2443 & 136 & 8,7 & 1,19 & 2543 & 0,05584 & 2,3 & 0,4102 & 4,9 & 0,47 & 0,01761 & 2,6 & 0,05328 & 4,3 & 350 & 8 & 349 & 15 & 353 & 9 & 341 & 98 \\
\hline 12 & a29 & 1405 & 77 & 4,9 & 1,52 & 10659 & 0,05608 & 1,9 & 0,4168 & 4,4 & 0,42 & 0,01726 & 2,8 & 0,05390 & 4,0 & 352 & 6 & 354 & 13 & 346 & 9 & 367 & 90 \\
\hline 13 & a31 & 5989 & 315 & 20 & 1,84 & 6043 & 0,05647 & 2,6 & 0,4085 & 8,7 & 0,30 & 0,01646 & 7,0 & 0,05247 & 8,3 & 354 & 9 & 348 & 26 & 352 & 9 & 325 & 104 \\
\hline 17 & a32 & 6545 & 382 & 24 & 1,11 & 51365 & 0,05445 & 2,2 & 0,3911 & 3,6 & 0,60 & 0,01687 & 7,8 & 0,05210 & 2,9 & 342 & 7 & 335 & 10 & 330 & 23 & 306 & 189 \\
\hline 18 & a33 & 3089 & 169 & 11 & 1,49 & 23416 & 0,05612 & 1,8 & 0,4173 & 3,9 & 0,47 & 0,01691 & 2,3 & 0,05393 & 3,4 & 352 & 6 & 354 & 12 & 338 & 26 & 290 & 66 \\
\hline 20 & a1 & 1719 & 100 & 6,3 & 0,96 & 6654 & 0,05534 & 2,2 & 0,4027 & 4,2 & 0,52 & 0,01719 & 2,7 & 0,05278 & 3,6 & 347 & 7 & 344 & 12 & 344 & 9 & 319 & 82 \\
\hline 21 & a2 & 2703 & 157 & 9,8 & 1,03 & 7837 & 0,05470 & 2,1 & 0,4045 & 4,4 & 0,47 & 0,01721 & 2,8 & 0,05364 & 3,9 & 343 & 7 & 345 & 13 & 345 & 10 & 356 & 87 \\
\hline 23 & a3 & 3086 & 182 & 11 & 0,95 & 9045 & 0,05498 & 2,1 & 0,4013 & 4,6 & 0,46 & 0,01782 & 2,8 & 0,05294 & 4,1 & 345 & 7 & 343 & 13 & 357 & 10 & 326 & 93 \\
\hline 28 & a5 & 8483 & 494 & 31 & 1,09 & 22129 & 0,05511 & 2,1 & 0,4071 & 3,0 & 0,69 & 0,01714 & 2,4 & 0,05358 & 2,2 & 346 & 7 & 347 & 9 & 344 & 8 & 354 & 50 \\
\hline 30 & a6 & 2326 & 135 & 8,5 & 1,49 & 8913 & 0,05556 & 2,1 & 0,4083 & 4,5 & 0,47 & 0,01706 & 2,2 & 0,05330 & 4,0 & 349 & 7 & 348 & 13 & 342 & 8 & 341 & 90 \\
\hline 31 & a7 & 3838 & 205 & 13 & 1,30 & 2977 & 0,05529 & 2,6 & 0,4039 & 5,3 & 0,49 & 0,01732 & 3,0 & 0,05299 & 4,6 & 347 & 9 & 345 & 16 & 347 & 10 & 328 & 105 \\
\hline 32 & a8 & 2321 & 134 & 8,5 & 1,39 & 1484 & 0,05538 & 2,3 & 0,4135 & 4,2 & 0,54 & 0,01740 & 3,0 & 0,05415 & 3,6 & 347 & 8 & 351 & 13 & 349 & 10 & 377 & 80 \\
\hline 35 & a9 & 6205 & 360 & 23 & 1,01 & 15170 & 0,05652 & 2,2 & 0,4125 & 3,7 & 0,59 & 0,01780 & 2,9 & 0,05293 & 3,0 & 354 & 7 & 351 & 11 & 357 & 10 & 326 & 68 \\
\hline 38 & $\mathrm{a} 10$ & 4757 & 281 & 18 & 1,06 & 1223 & 0,05483 & 2,3 & 0,4054 & 8,6 & 0,26 & 0,01717 & 3,3 & 0,05363 & 8,3 & 344 & 8 & 346 & 25 & 344 & 11 & 355 & 187 \\
\hline 40 & a11 & 7978 & 434 & 29 & 1,11 & 10637 & 0,05917 & 2,5 & 0,4410 & 4,0 & 0,63 & 0,01890 & 3,4 & 0,05406 & 3,1 & 371 & 9 & 371 & 13 & 378 & 13 & 374 & 71 \\
\hline 43 & $\mathrm{a} 12$ & 1094 & 67 & 4,1 & 0,79 & 4219 & 0,05396 & 2,8 & 0,3940 & 7,1 & 0,39 & 0,01724 & 3,1 & 0,05296 & 6,6 & 339 & 9 & 337 & 21 & 345 & 11 & 327 & 149 \\
\hline 45 & $\mathrm{a} 13$ & 3615 & 187 & 12 & 0,54 & 2780 & 0,05524 & 2,3 & 0,4109 & 7,3 & 0,32 & 0,01716 & 3,5 & 0,05395 & 6,9 & 347 & 8 & 350 & 22 & 344 & 12 & 369 & 155 \\
\hline 48 & $\mathrm{a} 14$ & 1484 & 89 & 5,7 & 1,19 & 5874 & 0,05674 & 2,4 & 0,4037 & 4,9 & 0,48 & 0,01735 & 2,5 & 0,05160 & 4,3 & 356 & 8 & 344 & 14 & 348 & 9 & 268 & 99 \\
\hline 49 & a15 & 5583 & 322 & 21 & 1,03 & 3131 & 0,05618 & 2,3 & 0,4199 & 4,0 & 0,56 & 0,01696 & 3,1 & 0,05420 & 3,3 & 352 & 8 & 356 & 12 & 340 & 10 & 380 & 75 \\
\hline 52 & a16 & 1581 & 96 & 6,0 & 1,26 & 6110 & 0,05470 & 2,1 & 0,3987 & 4,7 & 0,44 & 0,01699 & 2,8 & 0,05286 & 4,3 & 343 & 7 & 341 & 14 & 341 & 9 & 323 & 97 \\
\hline 53 & a17 & 2183 & 128 & 8,2 & 0,93 & 8320 & 0,05634 & 2,3 & 0,4164 & 4,3 & 0,52 & 0,01724 & 2,6 & 0,05360 & 3,7 & 353 & 8 & 353 & 13 & 346 & 9 & 354 & 84 \\
\hline 54 & a18 & 1362 & 84 & 5,3 & 1,05 & 5311 & 0,05493 & 2,3 & 0,3969 & 5,0 & 0,47 & 0,01723 & 2,9 & 0,05240 & 4,4 & 345 & 8 & 339 & 14 & 345 & 10 & 303 & 100 \\
\hline 55 & a19 & 6870 & 413 & 26 & 0,91 & 7615 & 0,05501 & 2,1 & 0,4069 & 3,4 & 0,61 & 0,01734 & 2,4 & 0,05364 & 2,7 & 345 & 7 & 347 & 10 & 347 & 8 & 356 & 61 \\
\hline
\end{tabular}

Table 2.- Results of U-Pb (LA-ICP-MS) zircon isotopic analyses of a medium- to coarse-grained Bt-granite clast (sample AN47) from the lower unit conglomerates of the Del Ratón Formation. 
Fig. 6.- Concordia plot of $\mathrm{U}-\mathrm{Pb}$ zircon isotopic analyses from medium- to coarse-grained Bt-granite clast of the Del Ratón conglomerate (sample AN47). Backscattered electron images of short-prismatic zircons with rhythmic concentric growth zoning.

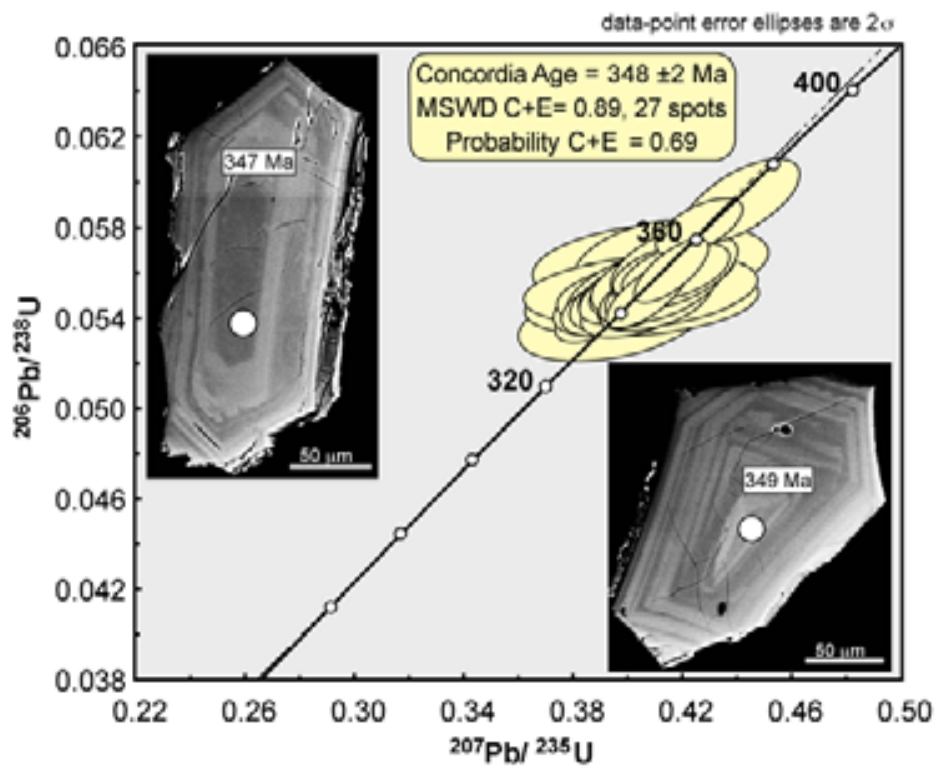

north, Martina et al. (2011) describe an important early Carboniferous volcanic event related to coeval A-type granites of the Sierras Pampeanas and also generated in an extensional environment. This volcanism consists of calc-alkaline/A-type rhyolites similar in age (348-342 Ma) to the granitic clast of the Del Ratón conglomerate.

To the W of the Precordillera, in the Andean Frontal Cordillera (Fig. 1b) there are no known early Carboniferous igneous rocks at this latitude. However, further south of the study area in the Frontal Cordillera of Mendoza, there are outcrops of calc-alkaline igneous rocks of Early Devonian-early Carboniferous age (Caminos et al., 1979; Gregori et al., 1996; Tickyj et al., 2009; Tickyj, 2011), for example the Pampa de las Avestruces granodiorite of Early Devonian age (Tickyj et al., 2009) and the Carrizalito Tonalite dated at $334 \pm 17 \mathrm{Ma}$ (K-Ar whole rock; Dessanti and Caminos, 1967). Also in this south sector (Cordón del Portillo) there is a plutonic association of gabbros and tonalites to granodiorites, and a volcanic sequence of andesites and dacites to rhyodacites and rhyolites (Polanski, 1972). One of these calc-alkaline rocks (Cerro Punta Blanca granodiorite) has been dated at $348 \pm 35 \mathrm{Ma}$ (Rb-Sr) and $337 \pm 15 \mathrm{Ma}$ (K-Ar) (Caminos et al., 1979). This calc-alkaline magmatism in the Frontal Cordillera of Mendoza has been interpreted as a magmatic arc (Tickyj, 2011), that could be associated with west-dipping subduction (Davis et al., 2000) prior to the accretion of the Chilenia terrane to the Precordillera (Cuyania terrane) and with crustal thickening during Chanic collision (Heredia et al., 2012).

\section{Geochemistry}

The geochemistry study of the igneous clasts in these conglomerates (Del Ratón and El Planchón) might test the possibility of a genetic relationship among the different clasts. In this way we could judge whether the clasts were derived from a single igneous complex or from unrelated intrusives.
Clast geochemistry is also an important tool to identify possible sources by comparison with known igneous complexes.

\subsection{Rock classification}

The studied conglomerates are formed by different igneous clasts, as previously shown in the field and petrography sections. The different composition of these clasts is also observed in their geochemistry (Table 3). The rock classification using immobile trace elements $(\mathrm{Nb}, \mathrm{Y})$ combined with major elements (Winchester and Floyd, 1977) defines these rocks as subalkaline basalts/gabbros (basic clasts), andesites, dacites/rhyodacites (intermediate clasts), and rhyolites/granites, comendites/pantellerites (acid clasts) (Fig. 7a). Regarding the two different conglomerates, the El Planchón conglomerate includes only basic clasts whereas the Del Ratón conglomerate contains basic-intermediate-acid clasts.

In the Del Ratón clasts, the Daly gap (Dickin et al., 1984) is observed in the lower abundance of intermediate clasts compared to the acid and basic ones. Some of the intermediate clasts from the Del Ratón conglomerate had a slight alkaline (A-type) signature defined by their higher content in $\mathrm{Zr}+\mathrm{Nb}+\mathrm{Ce}+\mathrm{Y}$ (Fig. 7b), but caution is necessary since many S-type peraluminous granitoids can also have such relatively high contents in these elements. Other geochemical parameters also indicate this alkaline signature for these samples (AN27, AN51): relatively high $\mathrm{Na}_{2} \mathrm{O}+\mathrm{K}_{2} \mathrm{O}-\mathrm{CaO}(\approx 7-8)$ and $\mathrm{Fe}_{2} \mathrm{O}_{3} \mathrm{t} / \mathrm{Fe}_{2} \mathrm{O}_{3} \mathrm{t}+\mathrm{MgO}(\approx 0.8)$ together with high Zr-saturation temperatures $\left(\mathrm{T}^{\circ} \mathrm{C} \approx 850-900\right)$.

Regarding peraluminosity, the basic clasts are metaluminous but two groups can be established (Fig. 7c): the El Planchón basic clasts have the lowest values of ASI $\left(\mathrm{Al}_{2} \mathrm{O}_{3} /\right.$ $\mathrm{Na}_{2} \mathrm{O}+\mathrm{K}_{2} \mathrm{O}+\mathrm{CaO}$ in molar proportions $\approx 0.4-0.6$ ) whereas the Del Ratón basic clasts display higher and more variable ASI values $(\approx 0.55-0.88-0.95)$. Such high values $(0.88-0.95)$ for these basic compositions are probably related to contamina- 
tion with peraluminous crustal lithologies or/and caused by higher sub-surface/surface alteration.

Intermediate and acid clasts from the Del Ratón conglomerate show variable ASI values, some of them are peraluminous to strongly peraluminous (AN52) while other clasts are metaluminous and metaluminous with elevated values of the agpaitic index $\left(\mathrm{Na}_{2} \mathrm{O}+\mathrm{K}_{2} \mathrm{O} / \mathrm{Al}_{2} \mathrm{O}_{3}\right.$ in molar proportions) and felsic compositions. The reason for these high values is the high content of $\mathrm{Na}_{2} \mathrm{O}$ relative to $\mathrm{K}_{2} \mathrm{O}$ and $\mathrm{Al}_{2} \mathrm{O}_{3}$ (AN47-50-51 with $\mathrm{Na}_{2} \mathrm{O}$ wt. $\%$ of $\approx 5-7.8$ ). These high $\mathrm{Na}_{2} \mathrm{O}$ contents produce high normative $\mathrm{Ab}$ values relative to normative $\mathrm{Or}$ and An giving a trondhjemitic signature to these rocks (Fig. 7d).
In order to compare the Del Ratón and El Plachón basic clasts with known compositions from mafic igneous rocks located nearby we have included in some of the plots the composition of Late Ordovician basalts and gabbros from the Western Precordillera (Sierra del Tigre basalts and gabbros; data from González-Menéndez et al., 2013). As observed in the figures $7 \mathrm{~b}$ and $\mathrm{c}$, the El Planchón basic clasts are similar to the mafic compositions of the Western Precordillera basalts and gabbros in $\mathrm{Zr}+\mathrm{Nb}+\mathrm{Ce}+\mathrm{Y}$ contents, as well as in ASI and $\mathrm{Na}_{2} \mathrm{O}+\mathrm{K}_{2} \mathrm{O} / \mathrm{CaO}$ values. On the other hand, the basic clasts from the Del Ratón conglomerate show higher ASI and $\mathrm{Na}_{2} \mathrm{O}+\mathrm{K}_{2} \mathrm{O} / \mathrm{CaO}$ values.

\begin{tabular}{|c|c|c|c|c|c|c|c|c|c|c|c|c|c|c|c|c|c|}
\hline \multirow{3}{*}{$\begin{array}{l}\text { Formation } \\
\text { R. Type } \\
\text { Sample }\end{array}$} & \multicolumn{12}{|c|}{ Del Ratón igneous clasts } & \multirow{2}{*}{\multicolumn{5}{|c|}{$\begin{array}{c}\text { El Planchón igneous clasts } \\
\underline{\text { Basic rocks }}\end{array}$}} \\
\hline & \multicolumn{3}{|c|}{ Basic rocks } & \multicolumn{4}{|c|}{ Intermediate rocks } & \multicolumn{5}{|c|}{$\underline{\text { Acid rocks }}$} & & & & & \\
\hline & AN20 & AN48 & AN24 & AN25 & AN22 & AN51 & AN-27 & AN26 & AN52 & AN49 & AN50 & AN47 & AN20b & AN20c & AN20e & AN20d & AN20a \\
\hline \multicolumn{18}{|c|}{ Major elements (wt \%) } \\
\hline $\mathrm{SiO}_{2}$ & 43.86 & 45.86 & 46.99 & 57.73 & 60.05 & 65.31 & 65.84 & 69.82 & 70.43 & 72.41 & 73.02 & 75.72 & 45.43 & 45.85 & 46.63 & 47.02 & 47.07 \\
\hline $\mathrm{TiO}_{2}$ & 1.98 & 2.08 & 1.95 & 0.89 & 0.63 & 0.83 & 0.81 & 0.43 & 0.45 & 0.39 & 0.27 & 0.19 & 1.67 & 2.18 & 1.60 & 1.72 & 1.79 \\
\hline $\mathrm{Al}_{2} \mathrm{O}_{3}$ & 16.65 & 16.15 & 14.74 & 18.09 & 16.54 & 15.48 & 15.16 & 12.94 & 14.59 & 12.54 & 11.75 & 12.11 & 10.15 & 14.46 & 14.80 & 14.86 & 16.17 \\
\hline $\mathrm{Fe}_{2} \mathrm{O}_{3}$ & 13.86 & 13.73 & 8.09 & 5.95 & 6.62 & 3.78 & 5.14 & 4.04 & 3.20 & 3.73 & 1.79 & 0.99 & 13.87 & 12.95 & 11.34 & 11.74 & 11.24 \\
\hline $\mathrm{MnO}$ & 0.38 & 0.30 & 0.26 & 0.10 & 0.12 & 0.10 & 0.09 & 0.09 & 0.06 & 0.07 & 0.06 & 0.04 & 0.21 & 0.19 & 0.17 & 0.17 & 0.18 \\
\hline $\mathrm{MgO}$ & 5.12 & 5.37 & 2.92 & 2.31 & 2.86 & 1.26 & 1.17 & 1.24 & 1.61 & 1.05 & 0.47 & 0.23 & 11.53 & 7.45 & 8.22 & 7.14 & 6.54 \\
\hline $\mathrm{CaO}$ & 6.45 & 7.47 & 10.24 & 4.42 & 5.36 & 1.95 & 1.05 & 1.26 & 0.38 & 0.50 & 2.62 & 1.22 & 12.69 & 11.04 & 12.10 & 11.50 & 11.58 \\
\hline $\mathrm{Na}_{2} \mathrm{O}$ & 3.10 & 2.54 & 4.40 & 4.53 & 2.66 & 7.86 & 4.59 & 3.61 & 1.14 & 3.90 & 5.02 & 6.9 & 1.16 & 2.05 & 1.79 & 2.19 & 2.47 \\
\hline $\mathrm{K}_{2} \mathrm{O}$ & 0.70 & 0.42 & 0.75 & 3.19 & 2.43 & 0.55 & 3.01 & 2.59 & 4.04 & 3.16 & 1.43 & 0.21 & 0.31 & 0.33 & 0.19 & 0.34 & 0.45 \\
\hline $\mathrm{P}_{2} \mathrm{O}_{5}$ & 0.19 & 0.21 & 2.14 & 0.25 & 0.18 & 0.42 & 0.02 & 0.10 & 0.14 & 0.06 & 0.11 & 0.03 & 0.14 & 0.21 & 0.13 & 0.15 & 0.17 \\
\hline LOI & 6.71 & 5.19 & 6.91 & 1.89 & 2.05 & 1.82 & 2.34 & 2.68 & 3.14 & 1.58 & 2.81 & 1.55 & 2.25 & 2.59 & 2.51 & 2.51 & 2.28 \\
\hline Total & 99.29 & 99.28 & 99.40 & 99.35 & 99.50 & 99.37 & 99.22 & 98.79 & 99.17 & 99.40 & 99.35 & 99.18 & 99.42 & 99.31 & 99.57 & 99.35 & 99.94 \\
\hline \multicolumn{18}{|c|}{ Trace elements (ppm) } \\
\hline V & 380 & 308 & 164 & 107 & 183 & 56 & 86 & 44 & 44 & 60 & 26 & 9 & 376 & 323 & 289 & 309 & 285 \\
\hline $\mathrm{Cr}$ & 351 & 199 & 48 & 25 & 79 & 3 & 30 & 21 & 6 & 6 & 3 & 4 & 422 & 324 & 614 & 312 & 212 \\
\hline Co & 51 & 58 & 32 & 32 & 43 & 39 & 42 & 40 & 25 & 39 & 45 & 140 & 66 & 52 & 55 & 50 & 53 \\
\hline $\mathrm{Ni}$ & 101 & 96 & 18 & 6 & 12 & 2 & 22 & 11 & 14 & 4 & & & 225 & 137 & 152 & 103 & 77 \\
\hline $\mathrm{Cu}$ & 393 & 42 & 10 & 18 & 12 & & 11 & 35 & 12 & 12 & & 10 & 95 & 162 & 119 & 118 & 106 \\
\hline $\mathrm{Zn}$ & 167 & 175 & 102 & 82 & 73 & 76 & 73 & 55 & 55 & 48 & 16 & 9 & 95 & 95 & 80 & 85 & 77 \\
\hline $\mathrm{Ba}$ & 236 & 130 & 118 & 1073 & 501 & 228 & 850 & 495 & 292 & 932 & 299 & 502 & 120 & 137 & 67 & 51 & 121 \\
\hline $\mathrm{Nb}$ & 7.8 & 9.9 & 15.9 & 9.2 & 7.4 & 37.2 & 33.1 & 22.6 & 24.6 & 20.3 & 18.5 & 22.9 & 6.6 & 8.1 & 5.8 & 7.1 & 7.5 \\
\hline $\mathrm{Rb}$ & 16 & 12 & 20 & 137 & 96 & 10 & 69 & 62 & 129 & 74 & 32 & 5 & 10 & 11 & 9 & 11 & 13 \\
\hline $\mathrm{Sr}$ & 336 & 360 & 575 & 494 & 332 & 292 & 262 & 131 & 48 & 206 & 123 & 115 & 180 & 266 & 215 & 238 & 242 \\
\hline$Y$ & 34 & 30 & 51 & 26 & 46 & 47 & 62 & 14 & 23 & 14 & 19 & 22 & 22 & 27 & 20 & 21 & 22 \\
\hline $\mathrm{Zr}$ & 124 & 146 & 282 & 360 & 131 & 587 & 548 & 212 & 294 & 207 & 139 & 156 & 90 & 118 & 78 & 90 & 105 \\
\hline $\mathrm{Pb}$ & 20 & 20.3 & 10.0 & 12.5 & 15.7 & 9.6 & 12.7 & 6.1 & 11.0 & 8.8 & 8.2 & 10.3 & 4.3 & 4.9 & 3.7 & 4.8 & 3.4 \\
\hline U & 1.9 & 1.0 & 3.5 & 4.9 & 1.7 & 2.4 & 2.0 & 2.0 & 1.7 & 1.6 & 3.3 & 1.8 & 2.2 & 1.6 & 1.6 & 2.0 & \\
\hline Th & & 1.1 & 4.7 & 9.7 & 9.0 & 8.1 & 12.3 & 11.2 & 8.4 & 9.9 & 13.7 & 13.3 & & & & & \\
\hline $\mathrm{Hf}$ & 3.90 & 3.68 & 5.10 & 8.30 & 4.00 & 13.74 & 12.70 & 4.20 & 8.46 & 5.37 & 4.70 & 5.27 & 2.33 & 3.23 & 2.37 & 2.48 & 2.62 \\
\hline $\mathrm{Ta}$ & 0.62 & 0.49 & 1.10 & 0.75 & 0.73 & 2.24 & 2.23 & 1.97 & 2.15 & 1.82 & 2.02 & 1.70 & 0.46 & 0.69 & 0.49 & 0.54 & 0.56 \\
\hline La & 20.08 & 25.27 & 94.60 & 30.48 & 23.18 & 108.40 & 78.71 & 54.37 & 49.89 & 14.02 & 42.75 & 40.94 & 7.02 & 10.38 & 7.12 & 7.56 & 8.25 \\
\hline $\mathrm{Ce}$ & 45.39 & 48.48 & 172.90 & 67.31 & 54.46 & 221.90 & 154.60 & 86.11 & 100.90 & 27.90 & 81.08 & 76.55 & 16.97 & 25.47 & 17.56 & 18.53 & 20.31 \\
\hline $\mathrm{Pr}$ & 6.35 & 6.26 & 23.94 & 9.21 & 7.45 & 24.57 & 19.45 & 11.49 & 11.58 & 3.32 & 8.34 & 7.35 & 2.38 & 3.75 & 2.45 & 2.59 & 2.86 \\
\hline $\mathrm{Nd}$ & 25.88 & 26.54 & 89.22 & 34.69 & 30.06 & 86.40 & 63.34 & 37.61 & 38.40 & 11.49 & 27.57 & 21.81 & 12.14 & 18.04 & 12.21 & 12.92 & 13.92 \\
\hline $\mathrm{Sm}$ & 6.38 & 6.18 & 15.95 & 6.68 & 7.35 & 13.52 & 11.31 & 5.56 & 5.94 & 2.22 & 4.53 & 3.39 & 3.48 & 4.93 & 3.47 & 3.62 & 3.89 \\
\hline $\mathrm{Eu}$ & 1.88 & 1.91 & 4.13 & 1.78 & 1.34 & 3.04 & 2.04 & 1.09 & 0.95 & 0.60 & 0.76 & 0.44 & 1.18 & 1.61 & 1.26 & 1.31 & 1.35 \\
\hline $\mathrm{Gd}$ & 7.03 & 6.60 & 15.62 & 6.25 & 7.66 & 12.08 & 12.43 & 5.13 & 5.37 & 2.21 & 4.14 & 3.39 & 3.89 & 5.30 & 3.78 & 4.01 & 4.16 \\
\hline $\mathrm{Tb}$ & 1.12 & 1.04 & 2.00 & 0.90 & 1.32 & 1.58 & 1.84 & 0.59 & 0.70 & 0.34 & 0.55 & 0.48 & 0.69 & 0.89 & 0.66 & 0.68 & 0.71 \\
\hline Dy & 6.62 & 6.21 & 10.07 & 4.94 & 8.37 & 8.79 & 11.26 & 2.84 & 4.12 & 2.20 & 3.21 & 3.08 & 4.14 & 5.28 & 3.97 & 4.13 & 4.26 \\
\hline Ho & 1.31 & 1.20 & 1.88 & 0.97 & 1.78 & 1.70 & 2.29 & 0.54 & 0.85 & 0.46 & 0.66 & 0.67 & 0.82 & 1.05 & 0.78 & 0.81 & 0.84 \\
\hline $\mathrm{Er}$ & 3.54 & 3.26 & 5.13 & 2.84 & 5.44 & 5.06 & 7.02 & 1.67 & 2.74 & 1.42 & 2.09 & 2.25 & 2.23 & 2.81 & 2.11 & 2.19 & 2.31 \\
\hline $\mathrm{Tm}$ & 0.49 & 0.45 & 0.66 & 0.42 & 0.83 & 0.72 & 1.08 & 0.27 & 0.44 & 2.23 & 0.34 & 0.39 & 0.32 & 0.41 & 0.31 & 0.32 & 0.33 \\
\hline $\mathrm{Yb}$ & 2.92 & 2.85 & 3.86 & 2.68 & 5.11 & 4.73 & 6.75 & 1.76 & 3.02 & 1.55 & 2.38 & 2.83 & 1.96 & 2.49 & 1.84 & 1.92 & 2.08 \\
\hline Lu & 0.41 & 0.39 & 0.58 & 0.40 & 0.74 & 0.71 & 1.02 & 0.27 & 0.47 & 0.25 & 0.36 & 0.43 & 0.28 & 0.36 & 0.27 & 0.28 & 0.30 \\
\hline
\end{tabular}

Table 3.- Whole-rock analyses of major and trace elements of the igneous clasts from the Del Ratón and El Planchón conglomerate formations. 

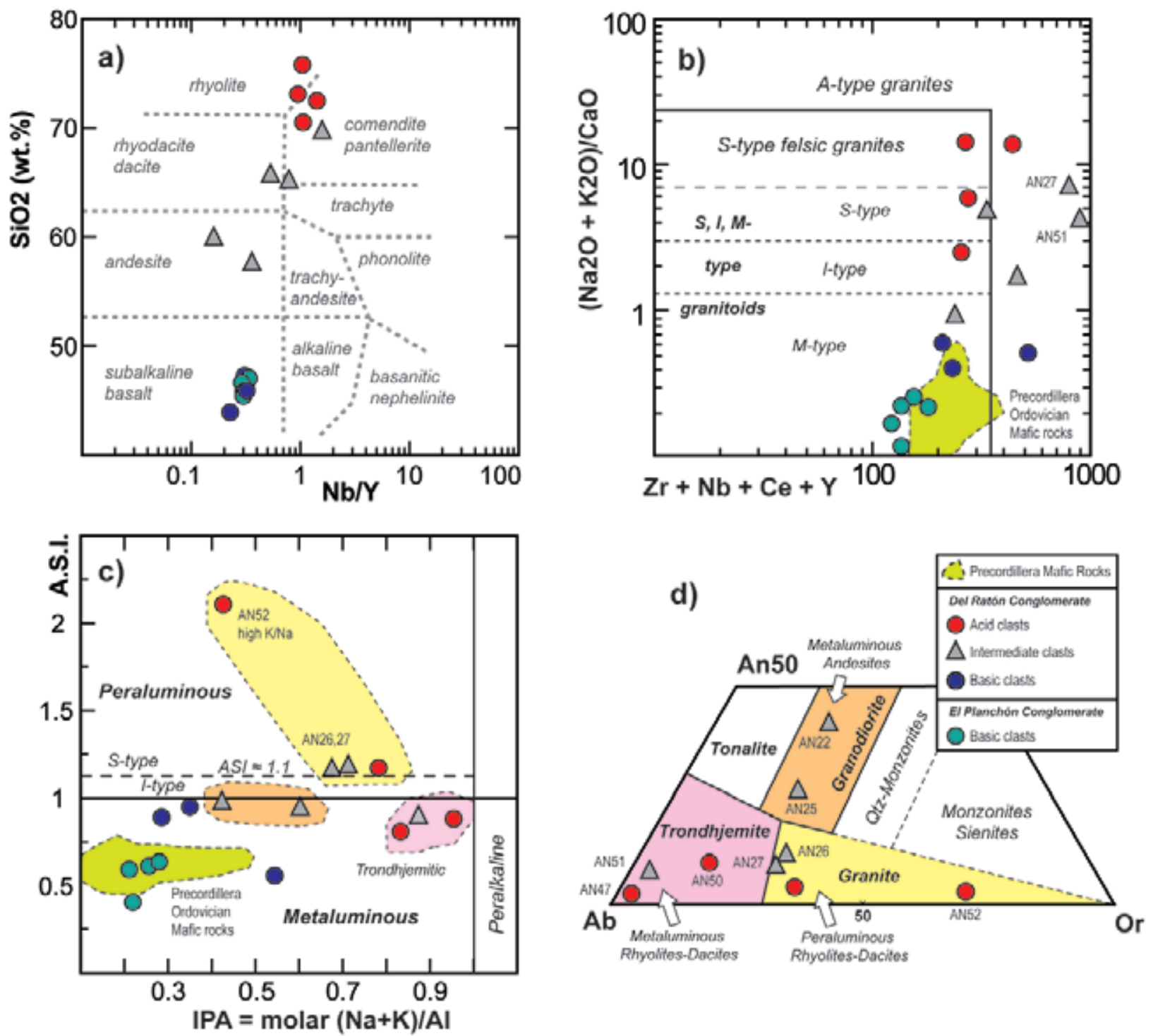

Fig. 7.- Geochemistry classifications of the Del Ratón and El Planchón igneous clasts. Data from the Western Precordillera Late Ordovician mafic rokcs is shown for comparison (González-Menéndez et al., 2013). a) Nb/Y vs. $\mathrm{SiO}_{2}$ classification diagram of Winchester and Floyd (1977). b) $\left(\mathrm{Na}_{2} \mathrm{O}+\mathrm{K}_{2} \mathrm{O} / \mathrm{CaO}\right)$ vs. $\mathrm{Zr}+\mathrm{Nb}+\mathrm{Ce}+\mathrm{Y}$ diagram of Whalen et al. (1987) for discriminating between A-type granitoids from other igneous rocks. c) Aluminium saturation index (A.S.I. $=\mathrm{Al}_{2} \mathrm{O}_{3} / \mathrm{CaO}+\mathrm{Na}_{2} \mathrm{O}+\mathrm{K}_{2} \mathrm{O}$, mol) vs. Agpaitic index $\left(\mathrm{I} . \mathrm{P} . \mathrm{A} .=\mathrm{Na}_{2} \mathrm{O}+\mathrm{K}_{2} \mathrm{O} / \mathrm{Al}_{2} \mathrm{O}_{3}, \mathrm{~mol}\right.$ ) with fields of peraluminous (S- and I-types), metaluminous and peralkaline granitoids. d) Triangular Ab-Or-An for felsic granitoid classification of O'cconor (1965) modified by Baker (1979).

\subsection{Geochemical variation trends}

When all the samples are plotted in Harker diagrams some correlations can be observed: $\mathrm{SiO}_{2}$ correlates well with $\mathrm{TiO}_{2}$ (Fig. 8a) and $\mathrm{Fe}_{2} \mathrm{O}_{3}$, but less with $\mathrm{MnO}, \mathrm{MgO}$, and $\mathrm{CaO}$. Other major elements such as $\mathrm{Al}_{2} \mathrm{O}_{3}, \mathrm{Na}_{2} \mathrm{O}, \mathrm{K}_{2} \mathrm{O}$, and $\mathrm{P}_{2} \mathrm{O}_{5}$ show no correlation with $\mathrm{SiO}_{2}$ (Fig. 8b, c). The elements $\mathrm{Na}_{2} \mathrm{O}$ and $\mathrm{K}_{2} \mathrm{O}$ are prone to alteration and hence mobile, which could explain the absence of correlations. On the other hand, when only intermediate and acid clasts are considered (Fig. 8b), decreasing $\mathrm{Al}_{2} \mathrm{O}_{3}$ correlates well with increasing $\mathrm{SiO}_{2}$. Correlations are also observed for some trace elements such as $\mathrm{V}, \mathrm{Sr}$ (decrease with increasing $\mathrm{SiO}_{2}$ ), and trace element ratios such as $\mathrm{Nb} / \mathrm{La}$ that increase slightly with increasing $\mathrm{SiO}_{2}$
(Fig. 8d, f). Other trace elements show considerable scatter (Ba, Nb, Y, Zr, REE, Th) except for Rb and $\mathrm{U}$, which have similar trends to $\mathrm{Sr}$ and $\mathrm{Al}_{2} \mathrm{O}_{3}$, decreasing with increase $\mathrm{SiO}_{2}$. All these trends could suggest an absence of petrogenetic relationship between the basic clasts and the intermediate-acid ones. The basic clasts fall away from the trends defined by the acid-intermediate ones for $\mathrm{Al}_{2} \mathrm{O}_{3}, \mathrm{~V}, \mathrm{Sr}, \mathrm{Rb}$, and $\mathrm{U}$. There are also some differences in trace element ratios such as $\mathrm{Nb} /$ $\mathrm{La}$, or $\mathrm{La} / \mathrm{Sm}$. Fractionation vectors were generated by linear mixing calculations (Ragland, 1989) for the intermediateacid clasts. A combination of $\mathrm{Pl}+\mathrm{Bt}+\mathrm{Amp}$ fractionation $(\approx$ $30 \% \mathrm{Amp}+40 \% \mathrm{Pl} ; 30 \% \mathrm{Bt}$ ) could explain part of the data such as the variations of $\mathrm{Al}_{2} \mathrm{O}_{3}$ and $\mathrm{TiO}_{2}$ with the $\mathrm{SiO}_{2}$ (Fig. $8 \mathrm{a}, \mathrm{b})$ but other element variations such as $\mathrm{Na}_{2} \mathrm{O}$ and $\mathrm{K}_{2} \mathrm{O}$ 

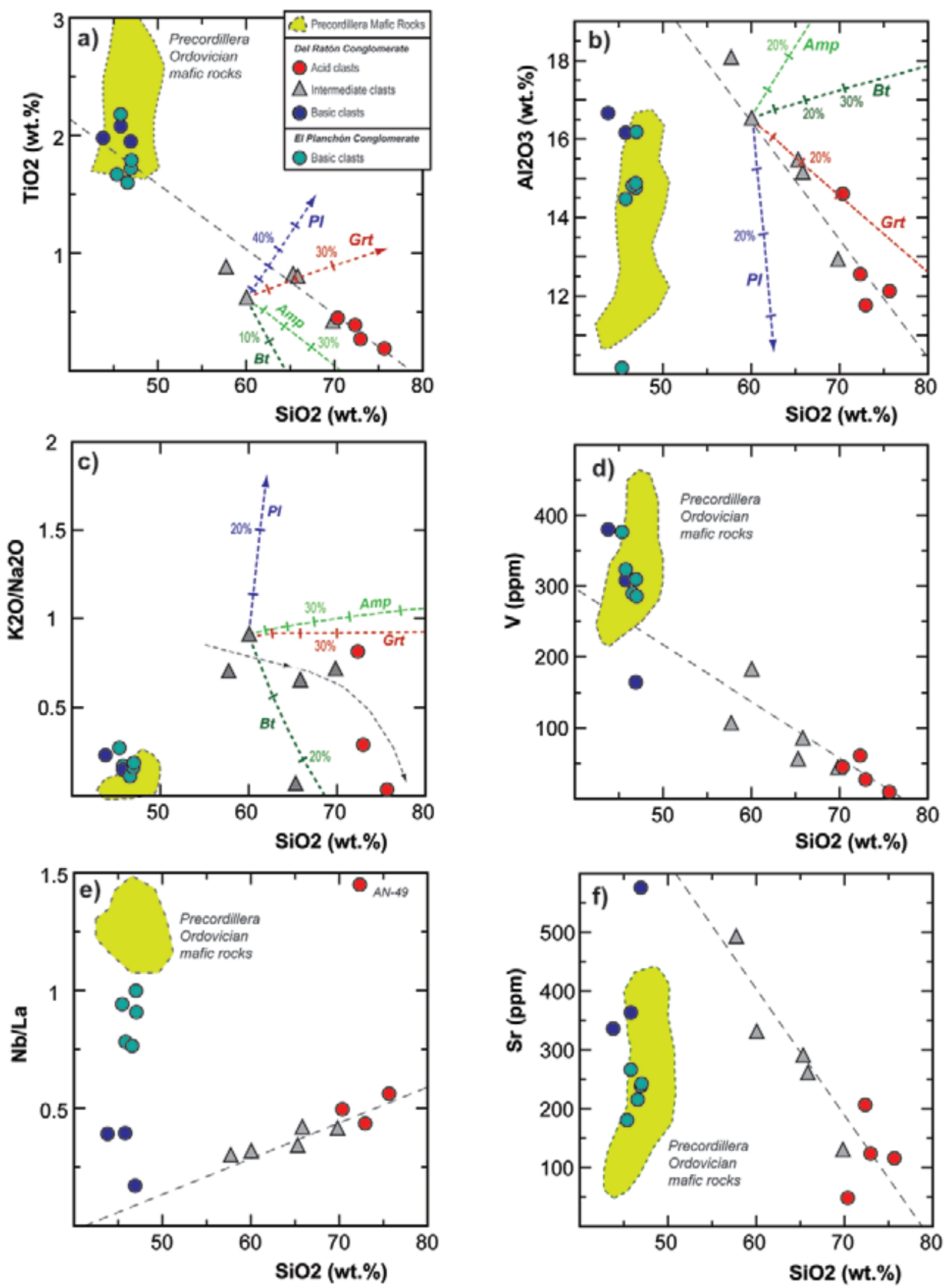

Fig. 8.- Diagrams of $\mathrm{SiO}_{2}$ vs. major and trace elements $\left(\mathrm{TiO}_{2}, \mathrm{Al}_{2} \mathrm{O}_{3}, \mathrm{~V}, \mathrm{Sr}\right)$ and element ratios $\left(\mathrm{K}_{2} \mathrm{O} / \mathrm{Na}_{2} \mathrm{O}, \mathrm{Nb} / \mathrm{La}\right)$. Black dashed line shows the approximate trend defined by part of the rocks plotted. Basic rocks fall away from these trends defined by the acid-intermediate compositions. Colour dashed lines are linear mixing models generated by the fractionation of different mineral phases from a selected starting composition (Del Ratón Formation sample AN22). Marks on the lines are intervals of 10\% crystallization. 
(Fig. 8c) cannot be reproduced with these calculations (this could also be valid for some of the mentioned scattered trace elements). This lack of adjustment to simple differentiation processes could be due to the effect of alteration or to a lack of direct petrogenetic relationship.

\subsection{Outstanding trace element features and REE data}

Some trace element ratios and the REE contents can help to identify the existence or absence of petrogenetic links among the different clasts of these conglomerates. The La/ $\mathrm{Nb}$ ratio can be used to investigate the volcanic arc vs. non arc-derived sources for basic to intermediate igneous rocks (Gill, 1981). The studied rock clasts show some scatter in the La vs. $\mathrm{Nb}$ diagram but two groups can be established (Fig.
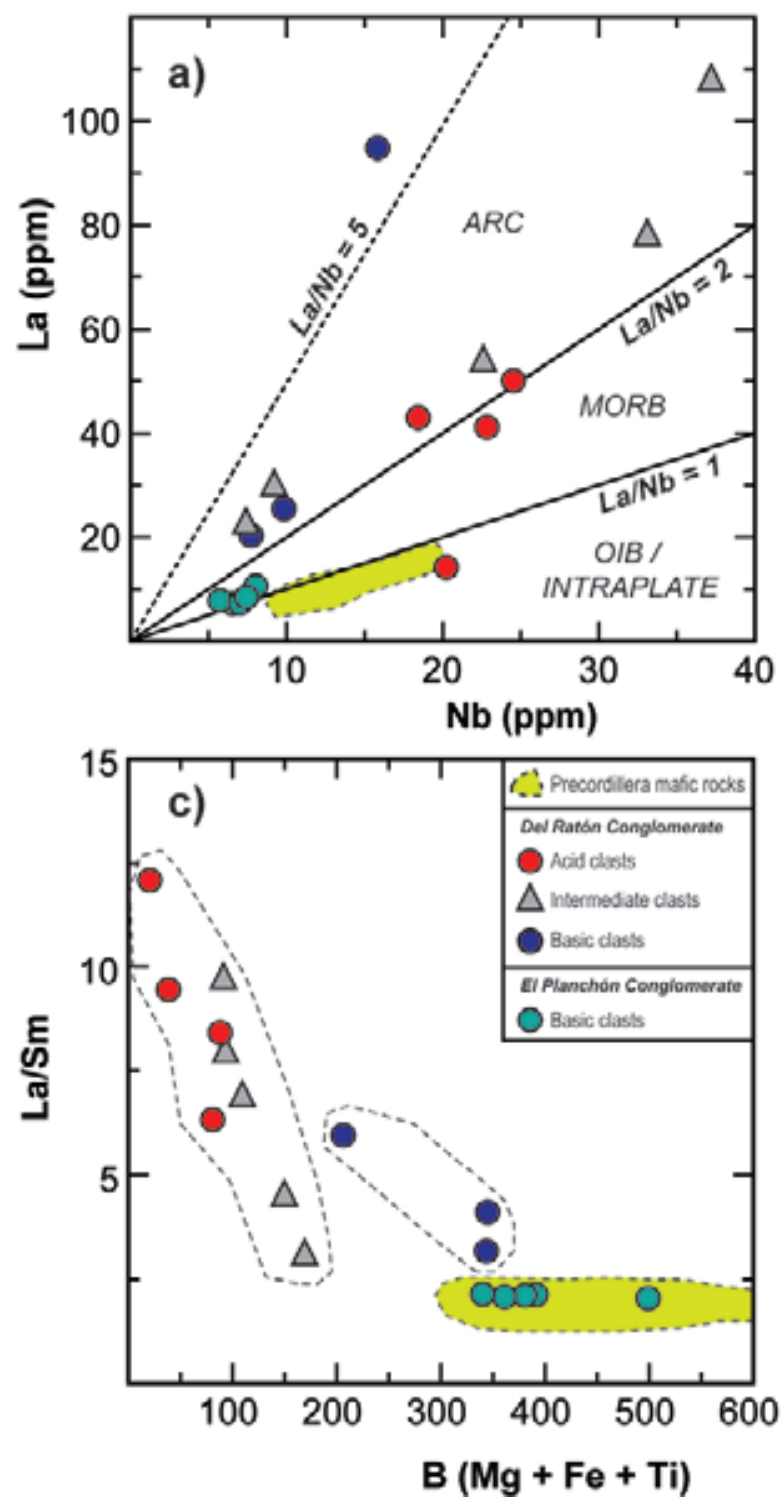

9a). Many of the Del Ratón clasts plot in the volcanic arc settings with $\mathrm{La} / \mathrm{Nb}>2$ values. The El Planchón basic clasts have $\mathrm{La} / \mathrm{Nb}$ values $<2$ and plot in the MORB field close to the Western Precordillera Late Ordovician basalts and gabbros (OIB/Within plate field). The $\mathrm{Nb} / \mathrm{La}$ ratios compared with the $\mathrm{Sr} / \mathrm{Nd}$ ones (Hawkesworth and Kemp, 2006) also show these differences: the basic clasts from the El Planchón conglomerate have $\mathrm{Nb} / \mathrm{La}-\mathrm{Sr} / \mathrm{Nd}$ compositions close to primitive mantle and MORB while the ones from the Del Ratón conglomerate plot close to upper and bulk crust values and also close to the field of continental arcs (Fig. 9b). Regarding REE, it is noticeable that the basic clasts from the Del Ratón conglomerate have high $\mathrm{La} / \mathrm{Yb}(>5)$ and La/ Sm (> 2.5) ratios compared to those from the El Planchón basic clasts, which have similar REE patterns to those of
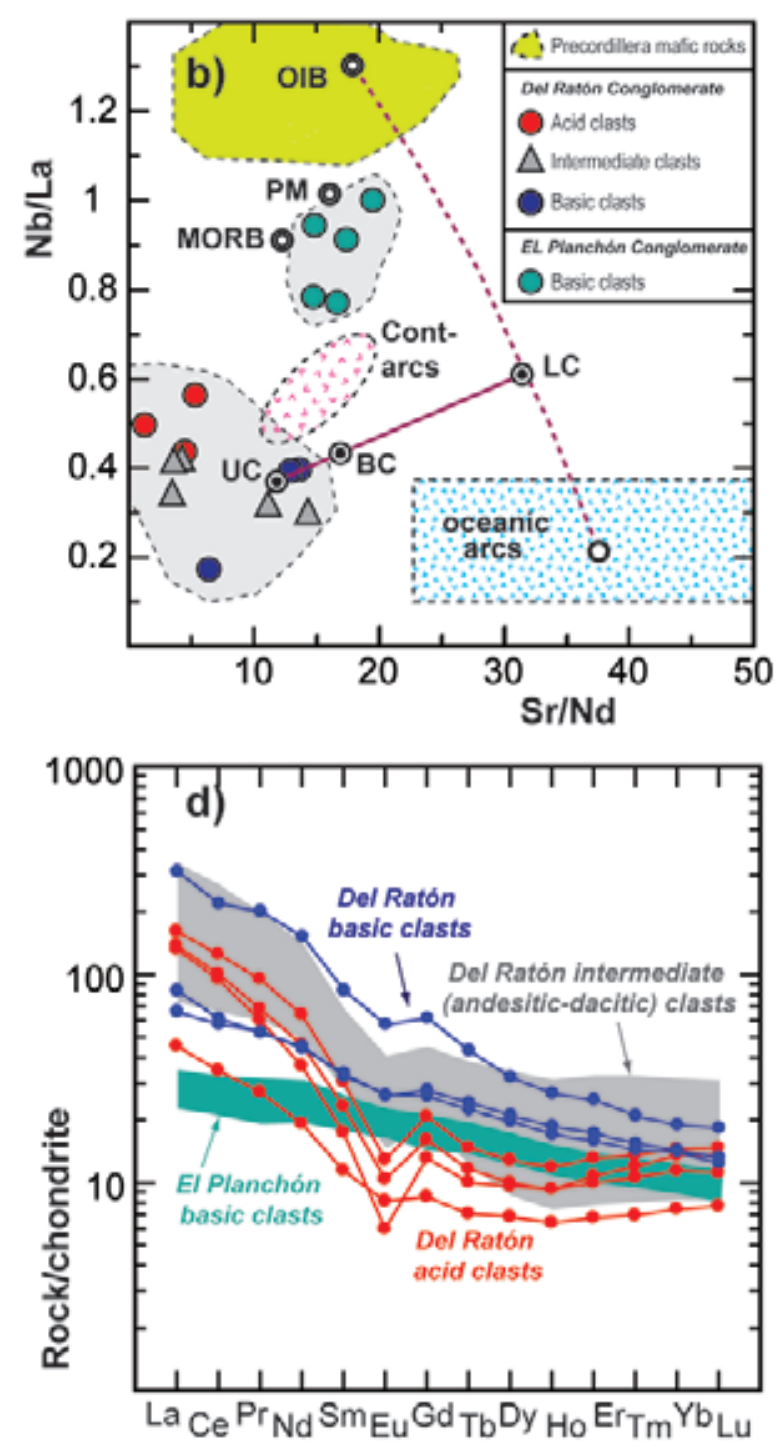

Fig. 9.- Trace and rare earth elements (REE) from the Del Ratón and El Planchón igneous clasts. a) Fields in the Nb vs La diagram are from Gill (1981). b) Fields and data in the Nb/La vs. Sr/Nd diagram are from Rudnick et al. (1995): MORB (Mid Ocean Rift Basalts), OIB (Oceanic Island Basalts), LC (Lower Crust), UC (Upper Crust), BC (Bulk Crust). c) La/Sm vs. B diagram. B parameter is from Debon and Lefort (1983) (B = Fe+Ti+Mg). d) REE diagram normalized to chondrites (Boynton, 1984). 
the Late Ordovician Precordillera basalts and gabbros. The $\mathrm{La} / \mathrm{Sm}$ vs. B ( $\mathrm{Mg}+\mathrm{Ti}+\mathrm{Fe}$ ) diagram (Fig. 9c) shows a correlation trend, defined by the Del Ratón intermediate-acid clasts, of increasing $\mathrm{La} / \mathrm{Sm}$ (LREE-MREE fractionation), with decreasing $\mathrm{B}$ (or with $\mathrm{SiO}_{2}$ increase) possibly related to increasing concentration of LREE rich accessories typical of felsic melts (Bea, 1996). The basic clasts from the Del Ratón conglomerate fall away from this trend suggesting an absence of petrogenetic relation to the intermediate-acid clasts.

The REE normalized patterns of the different clasts (Fig. 9d) show also the differences between the El Planchón basic clasts (smooth, low fractionated REE patterns, similar to those of tholeiites/enriched tholeiites, essentially without Eu negative anomalies) and the Del Ratón basic clasts. The latter show contrasting patterns, some samples have fractionated patterns with relatively high $\mathrm{La} / \mathrm{Yb}$ (6-8) but other samples (AN24) have much higher fractionation $(\mathrm{La} / \mathrm{Yb}=25)$ and similar $\mathrm{La} / \mathrm{Sm}$ values to some of the Del Ratón intermediate clasts. The Del Ratón intermediate and acid clasts have enriched LREE, marked Eu negative anomalies, and nearly flat HREE. The difference between these two groups (intermediate and acid clasts) lies in the absolute lower REE contents, higher LREE fractionation, and decreasing middle-heavy REE in the acid clasts. The comparison with other early Carboniferous igneous complexes such as A-type granitoids from the Sierras Pampeanas (Dahlquist et al., 2010; Alasino et al., 2012), located to the $\mathrm{E}$ and NE, and also to calc-alkaline granitoids from the Frontal Cordillera (Gregori et al., 1996), located to the SW, shows differences in both REE contents and normalized patterns (Fig. 10): A-type granitoids have higher total REE contents (some with significantly higher HREE), lower La/Sm ratios (flatter REE normalized patterns) and stronger negative Eu anomalies. Calc-alkaline granitoids show lower total contents of REE, lower La/Sm (but more similar to the Del Ratón clasts than A-type granitoids) and lower Eu anomalies.

\subsection{Normalized trace elements and further comparisons with other magmatic units}

Multi-element diagrams normalized to a primordial mantle composition (Sun and McDonough, 1989) were used for comparison between the studied conglomerates and possible igneous rock sources. As shown previously, the El Planchón basic clast compositions are different from the Del Ratón basic clasts. Their mantle-normalized pattern is smooth showing low fractionation between large ion lithophile elements (LILE) and high field strength elements (HFSE). Only some negative anomalies in $\mathrm{K}$ and $\mathrm{P}$ and slightly high $\mathrm{Rb}$ contents break this nearly flat pattern (Fig. 10a). This geochemistry is quite similar to that of the Late Ordovician basalts and gabbros from the Western Precordillera (data from GonzálezMenéndez et al., 2013). Some differences are the higher positive $\mathrm{Ba}$ and negative $\mathrm{K}$ anomalies and lower $\mathrm{Rb}$ contents of some of the Precordilleran basalts and gabbros (Fig. 10a).
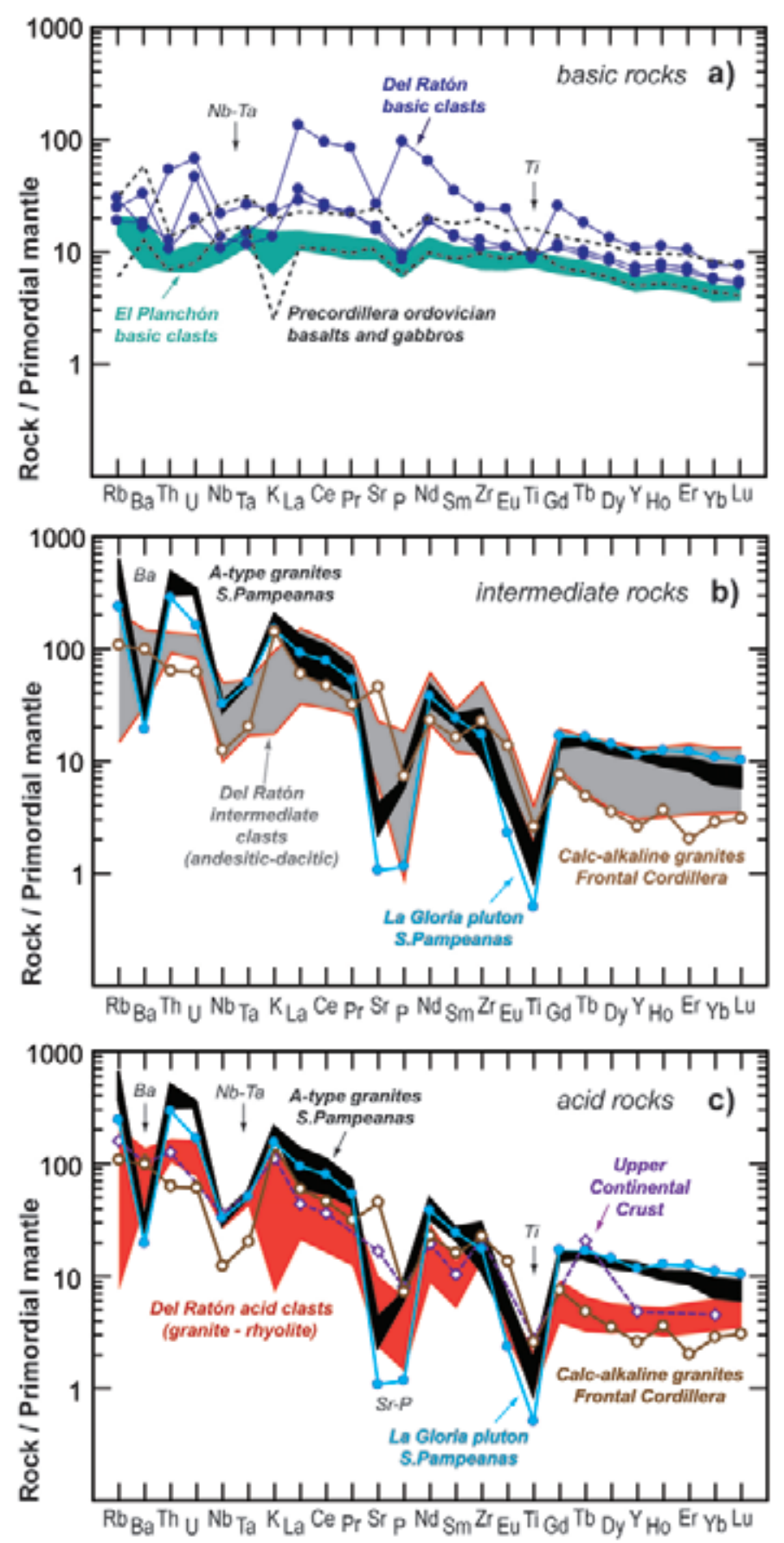

Fig. 10.- Multielement diagrams normalized to primordial mantle values (Sun and McDonough, 1989). Data from the Del Ratón and El Planchón conglomerates are plotted together with, basalts and gabbros from the Western Precordillera (González Menéndez et al., 2013), A-type granites from the Sierras Pampeanas (Dahlquist et al., 2010; Alasino et al., 2012), calc-alkaline granitoids from the Frontal Cordillera (Gregori et al., 1996), and average contents of the upper continental crust (Rollingson, 1993 and references therein. a) Basic clasts from the Del Ratón and El Planchón conglomerates. b) Intermediate clasts from the Del Ratón conglomerate. c) Acid clasts from the Del Ratón conglomerate.

The Del Ratón basic clasts have much higher contents in Th, $\mathrm{U}$, LREE, and negative anomalies in $\mathrm{Nb}-\mathrm{Ta}$, $\mathrm{P}$, and Ti. Some of these basic clasts have a normalized pattern similar to the intermediate clasts (Fig. 10b). The Del Ratón intermediate 
clasts have spiked mantle-normalized patterns with marked $\mathrm{Nb}-\mathrm{Ta}, \mathrm{P}$, and $\mathrm{Ti}$ negative anomalies and $\mathrm{Zr}$ positive ones (Fig. 10b). This pattern is similar to that of the upper continental crust (but somewhat higher in REE contents). The Del Ratón acid clasts (Fig. 10c) have normalized patterns similar to those of the intermediate clasts and display negative anomalies in $\mathrm{Nb}-\mathrm{Ta}, \mathrm{P}$ and $\mathrm{Ti}$ and positive ones in $\mathrm{Zr}$, but also show negative anomalies in $\mathrm{Sr}$ and $\mathrm{K}$ in some samples. The acid clasts normalized abundances are very similar to those of the upper continental crust.

For comparison with known possible early Carboniferous igneous sources, A-type igneous rocks (Dahlquist et al., 2010; Alasino et al., 2012) from the Sierras Pampeanas (located to the $\mathrm{E}$ and $\mathrm{NE}$ ) and representative calc-alkaline granitoids (Gregori et al., 1996) from the Frontal Cordillera (located to SW) were plotted on the multi-element diagrams (Fig. 10b, c). The selected A-type granitoids have marked negative anomalies in $\mathrm{Ba}$, positive ones in $\mathrm{Rb}-\mathrm{Th}-\mathrm{U}$, and very strong $\mathrm{Nb}-\mathrm{Ta}$ troughs. These are the main differences with the clasts from the Del Ratón conglomerate. In a more detailed comparison with the intermediate Del Ratón clasts, A-type granitoids also have stronger negative $\mathrm{Eu}, \mathrm{Sr}$ and $\mathrm{Ti}$ anomalies, and higher REE contents. The Frontal Cordillera calc-alkaline granitoids show a very similar pattern to the Del Ratón clasts with only slightly higher $\mathrm{Sr}$ and lower HREE than the intermediate clasts, and higher $\mathrm{Sr}$ and deeper $\mathrm{Nb}-\mathrm{Ta}$ trough than the acid clasts.

\section{Discussion}

\subsection{Geochemical relationships among the different clasts}

The petrography and geochemistry reveals that the basic clasts from the El Planchón conglomerate are different from the rest of the studied rocks. The geochemistry also indicates that the most probable source of the El Planchón basic clasts is the Late Ordovician basalts and gabbros of the Western Precordillera mafic belt (Haller and Ramos, 1984; Kay et al., 1984; Davis et al., 2000; Ramos et al., 2000; González Menéndez et al., 2013). Both have tholeiitic to transitional geochemistry probably related to extensional continental or continental-oceanic transitional settings (OIB/Withinplate/ MORB).

The basic clasts from the Del Ratón conglomerate have a subduction-related geochemistry $(\mathrm{Nb}$-Ta negative anomalies, elevated LILE/HFSE and La/Yb ratios, $\mathrm{La} / \mathrm{Nb}>2$ ) suggesting a provenance from a mantle arc source, or/and, from mantlederived basalts contaminated with continental crust materials.

Intermediate clasts from the Del Ratón conglomerate also have similar arc-related features and could have been derived by partial melting of mafic arc rocks. An alternative model could be that these intermediate rocks resulted from the magmatic differentiation of mafic arc magmas (crystal fractionation, crustal contamination). These supposed mafic precursors could be the basalt clasts mentioned above. The observed magmatic trends of the basic and intermediate rocks are substantially different for some elements (Al, Sr) but not for others ( $\mathrm{Ti}, \mathrm{V}, \mathrm{Mg}$ ), which seems to negate simple fractional crystallization or binary mixing.

Intermediate and acid clasts from the Del Ratón conglomerate could be related by straight differentiation (fractional crystallization) processes. The observed trends in the Harker diagrams (Fig. 8) are continuous between both groups of rocks (intermediate and acid clasts). The fractionation vectors calculated by linear mixing show that coupled fractionation of $\mathrm{Pl}+\mathrm{Amp}+\mathrm{Bt}$ could explain the actual trends for most of the major elements (Al, Ti, Mg, Mn, Ca, K, Na). The amphibole fractionation could also explain the middle-heavy REE decreasing in the acid clasts (Fig. 9d).

\subsection{Implications for the provenance of the clasts}

The composition of the clasts from the Del Ratón conglomerate and their comparison with the Frontal Cordillera calc-alkaline igneous rocks (Fig. 10) indicates a source area probably located along this Frontal Cordillera (Fig. 11a). In this N-S orientated range, the igneous calc-alkaline granitoids occur presently to the southwest of the Del Ratón outcrops. These calc-alkaline complexes are Devonian to early Carboniferous in age and mostly consists of igneous rocks including gabbros, tonalites, granodiorites, granites, andesites, dacites, rhyodacites and rhyolites (Polanski, 1972; Caminos et al., 1979; Gregori et al., 1996; Tickyj, 2011). Such a provenance is in agreement with the observed similar geochemistry of the Del Ratón clasts (Fig. 10b, c) and also with the U-Pb ( $\sim 348 \mathrm{Ma})$ age obtained in one of these clasts. The geochemistry also indicates that the acid and intermediate clasts probably come from a single igneous batholithic complex. The basic clasts, given their calc-alkaline signature, could be either mafic intrusives forming part of the same batholithic complex as the intermediate and acid clasts or derived from different intrusive units in other domains of the Frontal Cordillera. Recent palaeocurrent research (Colombo et al., 2012) indicates that the main provenance source for the Del Ratón clasts is from the Frontal Cordillera, from the west and northwest from its present outcrops. This contrasts with the absence of early carboniferous igneous rocks at this latitude. A possible solution is that such early Carboniferous calc-alkaline granitoids originally cropping out farther north in the Frontal Cordillera (Fig. 11a, b) have been oblitered by subsequent erosion and profuse Permo-Triassic plutonism (Colangüil batholith; Llambías and Sato, 1990, 1995; Sato et al., 1990) and volcanism (Choiyoi Group; Sato and Llambías, 1993; Llambías et al., 2003).

Another possible early Carboniferouos source for the Del Ratón conglomerate could be calc-alkaline/A-type rhyolites, A-type granites and syenogranites, alkaline S-type granodiorites to granites, and alkaline I-type tonalites to granites, located to the N and NE in the Sierras Pampeanas (Dahlquist et al., 2010; Martina et al., 2011; Alasino et al., 2012) (Fig. 

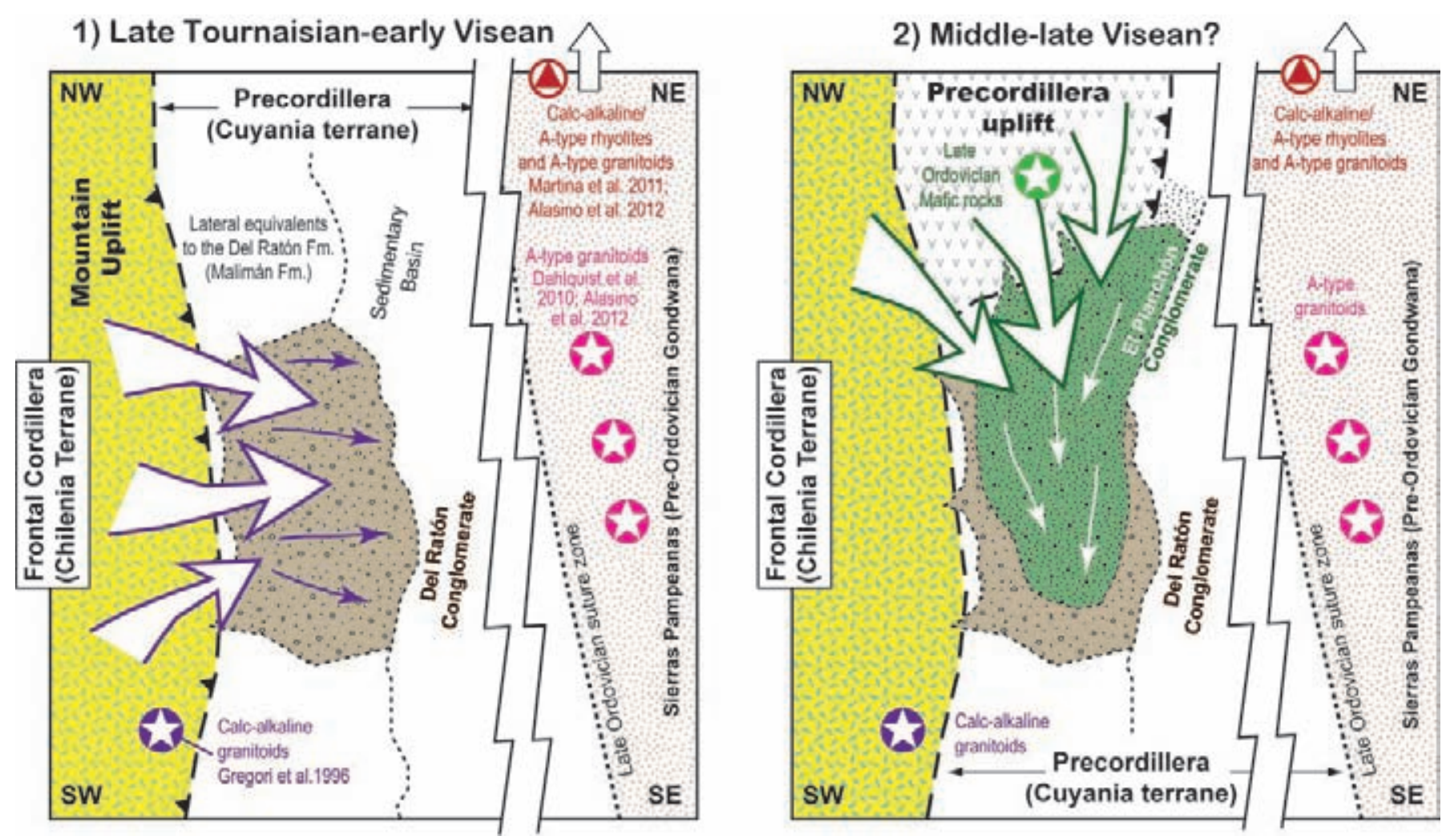

Fig. 11.- Schematic illustrations (no to scale) of the geological setting and possible sources of a) the Del Ratón conglomerates (late Tournaisianearly Visean) and b) the El Planchón conglomerates (middle-late Visean?). During the late Tournaisian-early Visean (a), the Frontal Cordillera (Chilenia terrane) was uplifted due to its collision with the Precordillera (Cuyania terrane). The Frontal Cordillera was composed at this time by calc-alkaline igneous rocks formed during a previous subduction event. Erosion of these igneous rocks and eastward sediment delivery generated the Del Ratón conglomerates (western provenance). Lateral equivalent facies of the Del Ratón Formation are the Malimán Formation to the north. This erosion processes probably removed many of the calc-alkaline igneous complexes and only south-southwest domains of the Frontal Cordillera still preserved the original calc-alkaline igneous rocks. Deformation was probably transferred eastwards, in the northern domains, causing uplift of a Precordillera basement block (Proto-Precodillera). Further erosion of this block produced the main sediment delivery towards the south and formed the El Planchón conglomerate (northern provenance).

11). However, their compositions (Fig. 10b, c) differ from those of the Del Ratón clats. The stratigraphic constraints of provenance from the W and NW (Colombo et al., 2012) also preclude such rocks as the source.

The petrography and geochemistry indicates that the sources of the El Planchón basic clasts are the Late Ordovician sedimentary formations (Alcaparrosa-Yerba Loca Formation) that according to Haller and Ramos (1984), Kay et al. (1984), Davis et al. (2000), and Ramos et al. (2000) host a significant volume of interlayered mafic volcanics and sills. This would indicate a provenance either from the north or south (in present coordinates). Possible source areas with the suitable basaltic compositions occur within $50 \mathrm{~km}$ (to both north and south). Northern provenance of these clasts (Fig. $11 \mathrm{~b}$ ) is the preferred hypothesis because it agrees with recent palaeocurrent studies (Colombo et al., 2012). Nevertheless, tholeiitic rocks of early Carboniferous age occur in southern locations of the Frontal Cordillera of Mendoza (Gregori et al., 1996). These rocks have similarities in composition to the El Planchón basic clasts and also to the Late Ordovician
Precordillera mafic rocks and therefore cannot be discarded as possible sources once located along the Frontal Cordillera (Fig. 11b).

The fact that the El Planchón conglomerate contains much older clasts (probably Late Ordovician) compared to the ones from the Del Ratón (early Carboniferous) has further significance since the Del Ratón Formation underlies the El Planchón Formation (Quartino et al., 1971; Alonso et al., 2005; Colombo et al., 2012). The fact that the older conglomerate (Del Ratón) includes younger clasts than the younger conglomerate (El Planchón) suggests that the first reliefs uplifted and eroded in the early Carboniferous ( $348 \mathrm{Ma})$ where those of the Frontal Cordillera (Fig. 11a) as also indicated by Colombo et al. (2012). These clasts were transported eastwards and were deposited in the locations where the Del Ratón Formation presently outcrops (i.e., western provenance). Afterwards, this sedimentary flux from the Frontal Cordillera was partially shut off, orogenic deformation was transferred towards the east (in the northern domains) and the Precordillera was probably uplifted (Proto-Precordillera 
block; Fig. 11b). The partial erosion of its early Palaeozoic formations produced the main clastic component delivery towards the south that formed the El Planchón conglomerate (northern provenance). This scenario suggests that the main uplift of the Frontal Cordillera domain was followed by uplifts farther east during the early to late Carboniferous period.

\section{Conclusions}

The Del Ratón conglomerate igneous clasts are basic, intermediate and acid rocks with calc-alkaline geochemical signatures. Laser ablation has yielded a U-Pb zircon age of $348 \pm 2$ Ma (late Tournaisian), interpreted as the maximum deposition age of this conglomerate formation. The Del Ratón clasts are similar in petrography and geochemistry to some early Carboniferous calc-alkaline complexes of the Frontal Cordillera suggesting provenance from the west or northwest. Frontal cordillera sources could have had one source location (a single igneous batholithic complex accounting for basicintermediate-acid clasts) or varied ones (accounting for the basic clasts and for the intermediate-acid clasts).

The basic igneous clasts from the El Planchón conglomerate are different from those of the Del Ratón. Their petrology and geochemistry is that of tholeiites from extensional continent-oceanic transition or intraplate settings without any arc signature. The similarities with Late Ordovician mafic igneous rocks of the western Precordillera suggest a provenance from the erosion of early Palaeozoic formations that outcrop in the Argentine Precordillera (north provenance). These formations usually contain abundant mafic volcanic and subvolcanic rocks (i.e. Late Ordovician Alcaparrosa-Yerba Loca Formation). Other possible sources along the Frontal Cordillera cannot be discarded but their clastic input was probably minor.

The erosional events that delivered the clasts of the Del Ratón and El Planchón formations were probably related to mountain range uplift episodes during the early $(\sim 348 \mathrm{Ma})$ Carboniferous period. Uplift seems to have migrated from the Frontal Cordillera domain (producing clasts transported eastwards to generate the Del Ratón conglomerate) eastwards to the Precordillera (shifting to clasts transported mainly from the north, generating the El Planchón conglomerates).

\section{Acknowledgments}

We greatly appreciate the review of R.J. Pankhurst for their constructive comments, and English corrections, which have improved the original manuscript. We thank C.O. Limarino, S.N. Césari, F. Colombo, N. Heredia and an anonymous reviewer for their suggestions. Catalina Suárez is thanked for producing maps figures. Financial support was provided by CGL2006-12415-C03 and CGL2009-13706-C03 projects (I+D+i Spanish Programmes) and FEDER Funds of the EU.

\section{References}

Alasino, P.H., Dahlquist, J.A., Pankhurst, R.J., Galindo, C., Casquet, C., Rapela, C.W. (2012): Early Carboniferous sub- to mid-alkaline magmatism in the Eastern Sierras Pampeanas, NW Argentina: A record of crustal growth by the incorporation of mantle-derived material in an extensional setting. Gondwana Research 22(3-4), 992-1008. doi: 10.1016/j.gr. 2011.12.011.

Alonso, J.L., Farias, P., Rodríguez Fernández, L.R., Heredia, N., García-Sansegundo J. (2005): Stratigraphic location of the Planchón Conglomerates (Western Argentine Precordillera, San Juan river). Abstracts Gondwana 12: Geological and Biological Heritage of Gondwana. Academia Nacional de Ciencias de Argentina (R.J. Pankhurst, G.D. Veiga, eds.), Mendoza, Argentina: p. 41.

Alonso, J.L., Gallastegui, J., García-Sansegundo J., Farias, P., Rodríguez Fernández, L.R., Ramos V.A. (2008): Extensional tectonics and gravitational collapse in an Ordovician passive margin: The Western Argentine Precordillera. Gondwana Research 13(2), 204-215. doi: 10.1016/j.gr. 2007.05.014.

Amenábar, C.R., di Pasquo, M. (2008): Nuevos aportes a la palinología, cronología y paleoambiente de la Precordillera occidental de Argentina: formaciones El Planchón, Codo (Devónico) y El Ratón (Mississippiano). Acta Geológica Lilloana 21(1), 3-20.

Astini, R.A. (1997): Las unidades calcáreas del Ordovícico Medio y Superior de la Precordillera Argentina como indicadores de una etapa extensional. Actas II Jornadas de Geología de Precordillera. San Juan, Argentina: 8-14.

Astini, R.A., Benedetto, J.L., Vaccari, N.E. (1995): The early Paleozoic evolution of the Argentine Precordillera as a Laurentia rifted, drifted and collided terrane: a geodynamic model. Geological Society of America Bulletin 107(3), 253-273. doi: 10.1130/0016-7606(1995)107<0253:TEPEOT>2.3.CO;2.

Astini, R.A., Martina, F., Dávila, F.D. (2011): La Formación Los Llantares en la Precordillera de Jagüe (La Rioja) y la identificación de un episodio de extension en la evolución temprana de las cuencas del Paleozoico superior en el oeste Argentino. Andean Geology 38(2), 245-267. doi: 10.5027/andgeoV38n2-a01.

Azcuy, C.L., Césari, S.N., Longobucco, M.I. (1981): Las plantas fósiles de la Formación El Ratón (Provincia de San Juan). Ameghiniana 18, 11-28.

Azcuy, C.L., Carrizo, H.A., Caminos, R. (2000): Carbonífero y Pérmico en las Sierras Pampeanas, Famatina, Precordillera, Cordillera Frontal y Bloque San Rafael. In: R. Caminos (ed.), Geología Argentina. Instituto de Geología y Recursos Minerales, Buenos Aires, Anales 29: 261-318.

Azcuy, C.A., Beri, A., Bernardes-de-Oliveira, M.E.C., Carrizo, H.A., di Pasquo, M.M., Díaz Saravia, P., González, C., Iannuzzi, R., Lemos, V.B., Melo, J.H.G., Pagani, A., Rohn, R., Rodríguez Amenábar, C., Sabattini, N., Souza, P.A., Taboada, A., Vergel, M.M. (2007): Bioestratigrafía del Paleozoico Superior de América del Sur: primera etapa de trabajo hacia una nueva propuesta cronoestratigráfica. Asociación Geológica Argentina, Serie D, Publicación Especial No 11: 9-65.

Baldis, B.A., Chebli, G. (1969): Estructura profunda del área central de la Precordillera sanjuanina. Cuartas Jornadas Geológicas Argentinas, 1, 47-66.

Barker, F. (1979): Trondjemite: Definition, enviroment, and hypotesis of origin. In: F. Barker (ed.), Trondjemites, dacites and related Rocks, Elsevier, Amsterdam: 1-12.

Bea, F. (1996): Residence of REE, Y, Th and U in granites and crustal protoliths; implications for the chemistry of crustal melts. Journal of Petrology 37(3), 521-552. doi:10.1093/petrology/37.6.1601.

Bordonaro, O. (1999): Cámbrico y Ordovícico de la Precordillera y Bloque de San Rafael. In: R. Caminos (ed.), Geología de Argentina. 
Subsecretaría de minería de la Nación, Instituto de Geología y Recursos Minerales. Anales 29(8): 189-204.

Boynton, W.V. (1984): Geochemistry of rare earth elements: Meteorite studies. In: P. Henderson (ed.), Rare Earth Element Geochemistry, Elsevier, New York: 63-114.

Bracaccini, O. (1946): Contribución al conocimiento geológico de la Precordillera Sanjuanina-Mendocina. Boletín de Informaciones petroleras, Buenos Aires, 258: 16-17.

Caminos, R., Cordani, U.G., Linares, E. (1979): Geología y geocronología de las rocas metamórficas y eruptivas de la Precordillera y Cordillera Frontal de Mendoza, República Argentina. Actas 1, Segundo Congreso Geológico Chileno, Arica, Chile: 43-61.

Césari, S.N., Gutiérrez, P.R. (2001): Palynostratigraphic study of the Upper Paleozoic central-western Argentinian sequences. Palynology 24, 113-146. doi: 10.2113/0240113.

Césari, S.N., Limarino, C.O., Gulbranson, E.L. (2011): An Upper Paleozoic bio-chronostratigraphic scheme for the western margin of Gondwana. Earth-Science Reviews 106, 149-160. doi.org/10.1016/j.earscirev.2011.01.012.

Colombo, F., Limarino, C.O., Spalletti, L.A., Cardó, R., Busquets, P., Méndez Bedia, I., Heredia, N. (2012): Unidades neopaleozoicas de la Precordillera de San Juan, Argentina. Características de las formaciones Ratón, Planchón y Salto. Resúmenes extendidos del VIII Congreso Geológico de España. CD anexo a Geo-Temas 13 (L.P. Fernández, A. Fernández, A. Cuesta, J.R. Bahamonde, eds.), Oviedo: 1863-1866.

Dahlquist, J.A., Alasino, P.H., Eby, G.N., Galindo, C., Casquet, C. (2010): Fault controlled Carboniferous A-Type magmatism in the proto-Andean foreland (Sierras Pampeanas, Argentina): geochemical constraints and petrogenesis. Lithos 115, 65-81. doi: 10.1016/j. lithos.2009.11.006

Dahlquist, J.A., Pankhurst, R.J., Rapela, C.W., Casquet, C., Fanning, C.M., Alasino, P., Baez, M. (2006): The San Blas Pluton: An Exemple of Carboniferous plutonismo in the Sierras Pampeanas, Argentina. Journal of South American Earth Sciences 20, 341-350. doi:10.1016/j. jsames.2005.08.006.

Dalziel, I.W.D. (1997): Neoproterozoic-Paleozoic geography and tectonics: Review, hypothesis, environmental speculation. Geological society of America Bulletin 109(1), 16-42. doi: 10.1130/0016-7606(1997)109<0016:ONPGAT>2.3.CO;2.

Davis, J.S., Roeske, S.M., McClelland, W.C., Kay, S.M. (2000): Mafic and ultramfic crustal fragments of the southwestern Precordillera terrane and their bearing on tectonic models of the early Paleozoic in western Argentina. Geology 28 (2), 171-174. doi: 10.1130/0091-7613(2000)28<171:MAUCFO>2.0.CO;2.

Davydov, V.I., Crowley, J.L., Schmitz, M.D., Poletaev, V.I. (2010): High-precision $\mathrm{U}-\mathrm{Pb}$ zircon age calibration of the global Carbonifeous time scale and Milankovitch band cyclicity in the Donets basin, eastern Ukraine. Geochemistry, Geophysics, Geosystems 11(2), 1-22. doi:10.1029/2009GC002736.

De Rosa, L.A. (1983): Sedimentitas continentales del Carbónico inferior del flanco occidental de la Precordillera, Dto. Calingasta-Pcia. de San Juan. Revista de la Asociación Argentina de Mineralogía, Petrología y Sedimentología 14, 51-59.

Debon, F., Le Fort, P. (1983): A chemical-mineralogical classification of common plutonic rocks and associations. Trans. R. Soc. Edinburgh: Earth Sci. 73, 135-149.

Dessanti, R., Caminos, R. (1967): Edades potasio-argón y posición estratigráfica de algunas rocas ígneas y metamórficas de la Precordillera, Cordillera Frontal y Sierras de San Rafael, provincia de Mendoza. Revista de la Asociación Geológica Argentina 22(2), 135-162.

Dickin, A.P., Brown, J.L., Thompson, R.N., Halliday, A.N., Morrison, M.A., Hutchinson, R., O'hara, M.J. (1984): Crustal contamination and granite problem in the British Tertiary Volcanic Province. Philo- sophical Transactions of the Royal Society of London, Series A310: 755-780.

Finney, S.C. (2007): The parautochthonous Gondwanan origin of the Cuyania (greater Precordillera) terrane of Argentine: A re-evaluation of evidence used to support an allochthonous Laurentia origin. Geologica Acta 5(2), 127-158. doi: 10.1344/105.000000300.

Frost, B.R., Barnes, C.G., Collins, W.J., Arculus, R.J., Ellis, D.J., Frost, C.D. (2001): A geochemical classification for granitic rocks. Journal of Petrology 42, 2033-2048. doi:10.1093/petrology/42.11.2033

Furque, G. (1956): Nuevos depósitos devónicos y carbónicos en la Precordillera sanjuanina. Revista de la Asociación Geológica Argentina 11(1), 46-71.

Furque, G. (1979): Descripción geológica de la Hoja 18c, Jáchal, Provincia de San Juan. Carta Geológico-Económica de la República Argentina, Escala 1:200.000. Servicio Geológico Nacional, Buenos Aires, Boletín 164: $79 \mathrm{p}$.

García de Madinabeitia, S., Sánchez Lorda, M.E., Gil Ibarguchi, J.I. (2008): Simultaneous determination of major to ultratrace elements in geological samples by fusion-dissolution and inductively coupled plasma mass spectrometry techniques. Analytica Chimica Acta 625(2), 117-130. doi.org/10.1016/j.aca.2008.07.024.

Gerdes, A., Zeh, A. (2006): Combined U-Pb and Hf isotope LA-(MC-) ICP-MS analyses of detrital zircons: Comparison with SHRIMP and new constraints for the provenance and age of an Armorican metasediment in Central Germany. Earth and Planetary Science Letters 249(1-2), 47-62. doi: 10.1016/j.eps1.2006.06.039.

Gerdes, A., Zeh, A. (2009): Zircon formation versus zircon alteration - new insights from combined $\mathrm{U}-\mathrm{Pb}$ and $\mathrm{Lu}-\mathrm{Hf}$ in situ LA-ICP-MS analyses, and consequences for the interpretation of Archean zircon from the Central Zone of the Limpopo Belt. Chemical Geology 261(3-4), 230-243. doi: 10.1016/j.chemgeo.2008.03.005.

Gill, J.B. (1981): Orogenic Andesites and Plate Tectonics. SpringerVerlag, Berlin: $380 \mathrm{p}$.

González-Menéndez, L., Gallastegui, G., Cuesta, A., Heredia, N., RubioOrdóñez, A. (2013): Petrogenesis of Early Paleozoic basalts and gabbros in the western Cuyania terrane: Constraints on the tectonic setting of the southwestern Gondwana margin (Sierra del Tigre, Andean Argentine Precordillera). Gondwana Research 24(1), 359-376. doi 10.1016/j.gr. 2012. 09. 011

Gosen, W. von (1997): Early Paleozoic and Andean structural evolution in the Río Jáchal section of the Argentine Precordillera. Journal of South American Earth Sciences 10(5-6), 361-388. doi.org/10.1016/ S0895-9811(97)00029-1.

Gregori, D.A., Fernández-Turiel, J.L., López-Soler, A., Petford, N. (1996): Geochemistry of Upper Palaeozoic-Lower Triassic granitoids of the Central Frontal Cordillera ( $\left.33^{\circ} 10-33^{\circ} 45\right)$, Argentina. Journal of South American Earth Sciences 9(1-2), 141-151. doi. org/10.1016/0895-9811(96)00034-X.

Grosse, P., Söllner, F., Báez, M.A., Toselli, A.J., Rossi, J.N., de la Rosa, J.D. (2009): Lower Carboniferous post-orogenic granites in central-eastern Sierra de Velasco, Sierras Pampeanas, Argentina: U-Pb monazite geochronology, geochemistry and Sr-Nd isotopes. International Journal of Earth Science (Geol Rundsch) 98, 1001-1025. doi: 10.1007/s00531-007-0297-5.

Guerstein, M., Laya, H., Pezutti, N. (1965): Bosquejo fotogeológico de la zona de "Las Juntas" (Dto. Calingasta, provincia de San Juan). Acta Geológica Lilloana 7, 231-242.

Haller, M.A., Ramos, V.A. (1984): Las ofiolitas famatinianas (Eopaleozoico) de las provincias de San Juan y Mendoza. Actas $2,9^{\circ}$ Congreso Geológico Argentino, Bariloche, Argentina: 66-83.

Hawkesworth, C.J., Kemp, A.I.S. (2006): The differentiation and rates of generation of the continental crust. Chemical Geology 226, 134 143. doi: 10.1016/j.chemgeo.2005.09.017.

Heim, A. (1952): Estudios tectónicos en la Precordillera de San Juan, en 
los ríos San Juan, Jáchal y Huaco. Revista de la Asociación Geológica Argentina 7, 11-70.

Heredia, N., Farias, P., García-Sansegundo, J., Giambiagi, L. (2012): The basement of the Frontal Cordillera in the Cordón del Plata (Mendoza, Argentina): Geodynamic Evolution. Andean Geology 39(2), 242-257. doi: 10.5027/andgeoV39n2-a03.

Jackson, S.E., Pearson, N.J., Griffin, W.L., Belousova, E.A., (2004): The application of laser ablation-inductively coupled plasma-mass spectrometry to in situ U-Pb zircon geochronology. Chemical Geology 211(1-2), 47-69. doi: 10.1016/j.chemgeo.2004.06.017.

Janoušek, V., Gerdes, A., Vrána, S., Finger, F., Erban, V., Friedl, G., Braithwaite, C.J.R. (2006): Low-pressure Granulites of the Lišov Massif, Southern Bohemia: Viséan Metamorphism of Late Devonian Plutonic Arc Rocks. Journal of Petrology 47, 705-744. doi:10.1093/ petrology/egi091.

Kay, S.M., Ramos, V.A., Kay, R. (1984): Elementos mayoritarios y trazas en las vulcanitas ordovícicas en la Precordillera Occidental: Basaltos de rift oceánico temprano (?) próximos al margen continental. Actas 2, $9^{\circ}$ Congreso Geológico Argentino, Bariloche: p. 48-65.

Keller, M. (1999): Argentine Precordillera: sedimentary and plate tectonic history of a Laurentia crustal fragment in South America. Geological Society of America Special Paper 341, 1-131. doi:10.1130/08137-2341-8.1

Keller, M., Lenhnert, O., Buggisch, W. (1993): The transition from diagenesis to low-grade metamorphism in the Argentine Precordillera: An application of the conodont colour alteration index. Actas 1, XII Congreso geológico Argentino y II Congreso de Exploración de Hidrocarburos: 294-299.

Kerlleñevich, S.C. (1967): Hallazgo del Devónico marino en la zona de Calingasta, provincia de San Juan. Revista de la Asociación Geológica Argentina 22, 291-294.

Llambías, E.J., Sato, A.M. (1990): El Batolito de Colangüil (29º-31으), Cordillera Frontal, Argentina: Estructura y marco tectónico. Revista Geológica de Chile 17(1), 89-108.

Llambías, E.J., Sato, A.M. (1995): El Batolito de Colangüil: transición entre orogénesis y anorogénesis. Revista de la Asociación Geológica Argentina 50(1-4), 111-131.

Llambías, E.J., Quenardelle, S., Montenegro, T. (2003): The Choiyoi Group fron central Argentina: a subalkaline transitional to alkaline association in the craton adjacent to the active margin of the Gondwana continent. Journal of South American Earth Science 16, 243-275. doi:10.1016/S0895-9811(03)00070-1.

Limarino, C.O., Césari, S.N. (1993): Reubicación estratigráfica de la Formación Cortaderas y definición del Grupo Angualasto (Carbonífero inferior, Precordillera de San Juan). Revista de la Asociación Geológica Argentina 47(1), 61-72.

Limarino, C.O., Spalletti, L.A. (2006): Paleogeography of the upper Paleozoic basins of southern South America: An overview. Journal of South American Earth Science 22, 134-155. doi:10.1016/j. jsames.2006.09.011.

Limarino, C.O., Tripaldi, A., Marenssi, S., Fauqué, L. (2006): Tectonic, sea-level, and climatic controls on Late Paleozoic sedimentation in the western basins of Argentina. Journal of South American Earth Science 22, 205-226. doi:10.1016/j.jsames.2006.09.009.

Limarino, C.O., Colombo, F., Busquets, P., Spalletti, L., Méndez-Bedia, I., Cardó, R. (2012): Aportes estratigráficos al conocimiento de la estructuración preandina entre $\operatorname{los} 29^{\circ}$ y $32^{\circ}$ de latitud sur, oeste argentino. Resúmenes extendidos del VIII Congreso Geológico de España. CD anexo a Geo-Temas 13 (Fernández, L.P., Fernández, A., Cuesta, A. y Bahamonde, J.R., eds.), Oviedo: 1891-1894.

López Gamundi, O.R., Rossello, E.A. (1993): Devonian-Carboniferous unconformity in Argentine and its relation to the Eo-Hercynian orogeny in southern South America. Geologische Rundschau 82(1), 136147. doi: 10.1007/BF00563276.
López Gamundi, O., Azcuy, C., Cuerda, A., Valencio, D., Vilas, J. (1987): Cuencas Río Blanco y Calingasta-Uspallata. In: S. Archangeisky (ed.), El sistema Carbonifero en la República Argentina, Academia Nacional de Ciencias, Córdoba, Argentina: 281-291.

Martina, F., Viramonte, J.M., Astini, R.A., Pimentel, M.M., Dantas, E. (2011): Mississippian volcanism in the south-central Andes: New U-Pb SHRIMP zircon geochronology and whole-rock geochemistry. Gondwana Research 19(2), 524-534. doi:10.1016/j.gr.2010.07.004.

O'Connor, J.T. (1965): A classification for quartz-rich igneous rocks based on feldspar ratios. U.S. Geological Survey Professional Paper 525B: B79-B84.

Polanski, J. (1972): Descripción Geológica de la Hoja 24 a-b, Cerro Tupungato, (Provincia de Mendoza). Boletín 165. Servicio Geológico Nacional, Secretaría de Estado de Minería: 117 p.

Pupin, J.P., Turco, G. (1972): Une typologie originale du zircon accessoire. Bulletin de la Société Française du Cristallografie 95, 348-59.

Quartino, B.J., Zardini, R.A., Amos, A. (1971): Estudio y exploración geológica de la region Barreal-Calingasta, Provincia de San Juan. Revista de la Asociación Geológica Argentina, Monografía 1: 184 p.

Ragland, P.C. (1989): Basic Analytical Petrology. Oxford University Press. New York.

Ramos, V.A. (1988): The tectonics of the Central Andes: $30^{\circ}$ to $33^{\circ} \mathrm{S}$ latitude. In: S. Clark and D. Burchfield (eds.), Processes in Continental Lithospheric Deformation. Geological Society of America Special Paper 218, 31-54.

Ramos, V.A., Folguera, A. (2009): Andean flat-slab subduction through time. Geological Society, London, Special Publications 327, 31-54. DOI: $10.1144 / \mathrm{SP} 327.3$.

Ramos, V.A., Escayola, M., Mutti, D.I., Vujovich, G.I. (2000): Proterozoic-early Paleozoic ophiolites of the Andean basement of South America. Geological Society of America Special Paper 349, 331-349. doi:10.1130/0-8137-2349-3.331.

Ramos, V.A., Jordan, T.E., Allmendinger, R.W., Kay, S.M., Cortés, J.M., Palma, M.A. (1984): Chilenia: un terreno alóctono en la evolución Paleozoica de los Andes Centrales. Actas 2. $9^{\circ}$ Congreso Geológico Argentino, Bariloche, Argentina: 84-106.

Ramos, V.A., Jordan, T.E., Allmendinger, R.W., Mpodozis, C., Kay, S.M., Cortés, J.M., Palma, M.A. (1986): Paleozoic Terranes of the Central Argentine-Chilean Andes. Tectonics 5(6), 855-880. doi: 10.1029/TC005i006p00855.

Rollingson, H. (1993): Using Geochemical Data: evaluation, presentation and interpretation. Longman: $352 \mathrm{p}$.

Sato, A.M., Llambías, E.J. (1993): El grupo Choiyoi, provincia de San Juan: equivalente efusivo del batolito de Colangüil. Actas IV, XII Congreso Geológico Argentino, II Congreso de Exploración de Hidrocarburos: $156-165$.

Sato, A.M., Llambías, E.J., Shaw, S.E., Castro, C.E. (1990): El Batolito de Colangüil: modelo del magmatismo neopaleozoico de la Provincia de San Juan. In: Relatorio de Geología y Recursos Naturales de la Provincia de San Juan. XI Congeso Geológico Argentino, Asociación Geológica Argentina: 100-123.

Scalabrini Ortiz, J. (1973): El Carbónico en el sector septentrional de la Precordillera sanjuanina. Revista de la Asociación Geológica Argentina 27(4), 351-377.

Sessarego, H.L.F. (1983): La posición estratigráfica y edad del conglomerado atribuido a la Formación del Salto. Río San Juan, Provincia de San Juan. Revista de la Asociación Geológica Argentina 38, 494-497.

Sessarego, H.L.F. (1988): Estratigrafia de las secuencias epiclásticas devónicas a triásicas aflorantes al norte del río San Juan y al oeste de las Sierras del Tigre, provincia de San Juan. PhD Thesis, Universidad de Buenos Aires, (unpublished).

Sessarego, H.L.F., Césari, S.N. (1986): La zona (de conjunto) Archaeosigillaria-Lepidodendropsis del carbonífero temprano de Argentina. Abstract Annual meeting Project 21 1-IGCP, Córdoba, Argentina: 
69-70.

Sessarego, H.L.F., Césari, S.N. (1988): An Early Carboniferous Flora from Argentina. Biostratigraphic implications. Rewiev of Palaeobotany and Palynology 57(3-4), 247-264. doi.org/10.1016/00346667(89)90023-7.

Sessarego, H.L.F., Amos, A.J., Teixeira, W., Kawashita, K., Remesal, M.A. (1990): Diques Eocarbónicos en la Precordillera Occidental, margen oeste de las Sierras del Tigre. Provincia de San Juan. Revista de la Asociación Geológica Argentina 45, 98-106.

Spalletti, L.A., Cingolani, C., Varela, R., Cuerda, A. (1989): Sediment gravity flow deposits of an Ordovician deep-sea fan system (western Precordillera, Argentina). Sedimentary Geology 61(3-4), 287-301. doi: 10.1016/0037-0738(89)90063-8.

Sun, S.-s., McDonough, W.F. (1989): Chemical and isotopic systematic of oceanic basalts: implications for mantle composition and processes. In: A.D. Saunders and M.J. Norry (eds), Magmatism and Ocean Basins, Geological Society, London, Special Publications 42, 313345. doi:10.1144/GSL.SP.1989.042.01.19.

Thomas, W.A., Astini, R.A. (2003): Ordovician accretion of the Argentine Precordillera terrane to Gondwana: a review. Journal of South American Earth Sciences 16, 67-79. doi:10.1016/S08959811(03)00019-1.

Thomas, W.A., Astini, R.A., Bayona, G. (2002): Ordovician collision of the Argentine Precordillera with Gondwana, independent of Laurentian Taconic orogeny. Tectonophysics 345, 131-152. doi: 10.1016/ S0040-1951(01)00210-4.
Tickyj, H. (2011): Granitoides calcoalcalinos Tardío-Famatinianos en el Cordón del Carrizalito, Cordillera Frontal, Mendoza. Actas CD, I.G. Petrología Ígnea y Metamórfica, Congreso Geológico Argentino, No 18, Neuquén, Argentina: 2 p.

Tickyj, H., Fernández, M.A., Chemale Jr., F. y Cingonali, C. (2009): Granodiorita Pampa de los Avestruces, Cordillera Frontal, Mendoza: un intrusivo sintectónico de edad Devónica inferior. Libro de Resúmenes 27, XIV Reunión de Tectónica. Río Cuarto, Córdoba, Argentina.

Tófalo, O.R., De Rosa, L., Turco Greco, E., Forzinetti, M.E., Asaro, M. (1985): Análisis estadístico de los rodados de la Formación del Ratón (Carbónico), en Calingasta, San Juan. Bol. Sedimentológico 2-3, 4965 .

Walker, J.D., Geissman, J.W., Bowring, S.A., Babcock, L.E. (2012): The Geological Society of America Geologic Time Scale. Geological Society of America. doi: 10.1130/B30712.1.

Whalen, J.B., Currie, K.L., Chappell, B.W. (1987): A-type granites: Geochemical characteristics, discrimination and petrogenesis: Contributions to Mineralogy and Petrology 95, 407-419. DOI: 10.1007/ BF00402202.

Whitney, D., Evans, B. (2010): Abbreviations for names of rock-forming minerals. American Mineralogist 95, 185-187. doi: 10.2138/ am.2010.3371.

Winchester, J.H., Floyd, P.A. (1977): Geochemical discrimination of different magma series and their differentiation products using immobile elements. Chemical Geology 20, 325-343. doi: 10.1016/00092541(77)90057-2. 